\title{
The Novel Role of PPAR Alpha in the Brain: Promising Target in Therapy of Alzheimer's Disease and Other Neurodegenerative Disorders
}

\author{
Sylwia Wójtowicz ${ }^{1}\left[\right.$. Anna K. Strosznajder ${ }^{2} \cdot$ Mieszko Jeżyna $^{2} \cdot J^{\prime}$ Joanna B. Strosznajder ${ }^{1}$
}

Received: 8 December 2019 / Revised: 11 February 2020 / Accepted: 17 February 2020 / Published online: 13 March 2020

(c) The Author(s) 2020

\begin{abstract}
Peroxisome proliferator activated receptor alpha (PPAR- $\alpha$ ) belongs to the family of ligand-regulated nuclear receptors (PPARs). These receptors after heterodimerization with retinoid X receptor (RXR) bind in promotor of target genes to PPAR response elements (PPREs) and act as a potent transcription factors. PPAR- $\alpha$ and other receptors from this family, such as PPAR- $\beta / \delta$ and PPAR- $\gamma$ are expressed in the brain and other organs and play a significant role in oxidative stress, energy homeostasis, mitochondrial fatty acids metabolism and inflammation. PPAR- $\alpha$ takes part in regulation of genes coding proteins that are involved in glutamate homeostasis and cholinergic/dopaminergic signaling in the brain. Moreover, PPAR- $\alpha$ regulates expression of genes coding enzymes engaged in amyloid precursor protein (APP) metabolism. It activates gene coding of $\alpha$ secretase, which is responsible for non-amyloidogenic pathway of APP degradation. It also down regulates $\beta$ secretase (BACE-1), the main enzyme responsible for amyloid beta (A $\beta$ ) peptide release in Alzheimer Diseases (AD). In AD brain expression of genes of PPAR- $\alpha$ and PPAR- $\gamma$ coactivator -1 alpha (PGC- $1 \alpha$ ) is significantly decreased. PPARs are altered not only in AD but in other neurodegenerative/neurodevelopmental and psychiatric disorder. PPAR- $\alpha$ downregulation may decrease anti-oxidative and anti-inflammatory processes and could be responsible for the alteration of fatty acid transport, lipid metabolism and disturbances of mitochondria function in the brain of AD patients. Specific activators of PPAR- $\alpha$ may be important for improvement of brain cells metabolism and cognitive function in neurodegenerative and neurodevelopmental disorders.
\end{abstract}

Keywords PPAR- $\alpha \cdot$ Glutamatergic signaling $\cdot$ App/a $\beta$ metabolism $\cdot$ Mitochondria function $\cdot$ Neurodegeneration $\cdot$ Neuroprotection

\section{Introduction}

Peroxisome proliferators activated receptors (PPARs) are family of ligand-regulated nuclear receptors that include PPAR- $\alpha$, PPAR- $\beta / \delta$ and PPAR- $\gamma$. These receptors are encoded by distinct genes: PPAR- $\alpha$ (NR1C1), PPAR- $\beta / \delta$ (NUC1 or NR1C2) and PPAR- $\gamma$ (NR1C3) located on chromosome 15, 17, and 6 in the mouse and on chromosome 22,

\footnotetext{
Sylwia Wójtowicz

swojtowicz@imdik.pan.pl

$\triangle$ Joanna B. Strosznajder

jstrosznajder@imdik.pan.pl

1 Department of Cellular Signaling, Mossakowski Medical Research Centre Polish Academy of Sciences, 5 Pawińskiego st., 02-106 Warsaw, Poland

2 Faculty of Medicine, Medical University of Bialystok, 1 Kilinskiego st., 15-089 Białystok, Poland
}

6,3 in humans. The PPAR- $\gamma$ gene alternative promotors are responsible for three isoforms $(\gamma 1, \gamma 2, \gamma 3)$ These PPARs genes encode proteins of 468, 441, 475 and 505 amino acids with 49-56 kDa [1, 2].

PPARs regulate transcriptions through a complex mechanism as described in review by Berger and Moller [3] and Nierenberg et al. [4]. The first PPAR currently known as PPAR- $\alpha$ was discovered in 1990 [5]. PPARs after heterodimerization with RXR bind to the specific promotor region of target genes described as PPAR response elements (PPREs) and act as transcription factor(s) [4]. PPARs coactivators, such as PPAR- $\gamma$ coactivator- 1 alpha (PGC1- $\alpha$ ), exert significant role in transcription of genes through interaction not only with PPARs but also with other nuclear receptors as estrogen receptors (ERs) and nuclear respiratory factors 1 and 2 (NRF1, NRF2) [6]. These receptors play a significant role in the regulation of transcription, energy and lipid metabolism and also in thermogenesis. PPAR- $\alpha$ regulates 
mitochondria metabolism, including fatty acids $\beta$ oxidation pathway, energy processes, glucose metabolism, redox state and glutamatergic, cholinergic/dopaminergic neurotransmission. Additionally, PPAR- $\alpha$ is engaged in metabolism of amyloid beta precursor protein (APP) in the brain and directly or indirectly through $\mathrm{A} \beta$ it may also influence Tau protein phosphorylation. (Fig. 1) PPAR- $\beta / \delta$ regulates differentiation of cells, lipid metabolism and myelination processes in central nervous system (CNS) [7]. PPAR- $\gamma$ and its coactivator PGC-1 $\alpha$ play an important role in cell differentiation and mitochondria biogenesis in neurodegeneration and neuroinflammation [8-10].

The purpose of this review is to describe the role of PPAR- $\alpha$ in the brain in neurodegenerative and psychiatric disorders and demonstrate that this receptor could be a promising target in novel therapeutic strategies.

\section{PPAR- $\alpha$ and Its Role in Neurotransmission in the Brain}

The data of Warden et al. [11] were the first to describe PPARs distribution in the brain and defined their cell type profiles in adult mouse and in human brain specific regions, which are implicated in neurodegenerative diseases. The usage of double immunofluorescence showed that only PPAR- $\alpha$ co-localizes with all cell types in adult mouse and adult human brain. Furthermore, the authors pointed out, that after lipopolysaccharide (LPS) injection evoking strong neuro-immune response, the significant neuronal localization of all PPARs was found with very weak co-localization of PPAR- $\gamma$ in microglia.

Moreover, Roy et al. [12] determined the distribution of PPAR- $\alpha$ in different regions of hippocampus and observed that PPAR- $\alpha$ protein was localized in CA1, CA2, and CA3 and in dentate gyrus (DG) of mice brain. It was found that PPAR- $\alpha$ controls calcium influx and the expression of several genes coding hippocampal proteins involved in regulation of synaptic plasticity. PPAR- $\alpha$ is engaged in expression of $N$-methyl-D-aspartate (NMDA) receptor subunit NR2A and NR2B genes [13] and 2-amino-3(3-hydroxy-5-methylisoxasol-4-yl) propanoic acid AMPA receptor-associated subunit GluR1 [14], and also AMPA-receptor associated activity-related cytoskeleton proteins [15]. All these mentioned genes are related to synaptic plasticity and are regulated by PPAR- $\alpha$ via cyclic AMP response element binding protein (CREB). According to data of Roy et al. [12], PPAR $\alpha$ - null mice are deficient in CREB and memories associated proteins and have decreased spatial learning and memory.

The further study demonstrated that PPAR- $\alpha$ and its ligands are involved in regulation of glutamatergic and cholinergic mediated dopaminergic transmission in the brain [16-21]. The PPAR- $\alpha$ signaling may lead to alteration of genes transcription of enzymes that are engaged in metabolism of endogenous antagonists of glutamatergic receptors and may promote glutamate transporter-1 (GLT-1)

\section{TAU HYPERPHOSPHORYLATION}

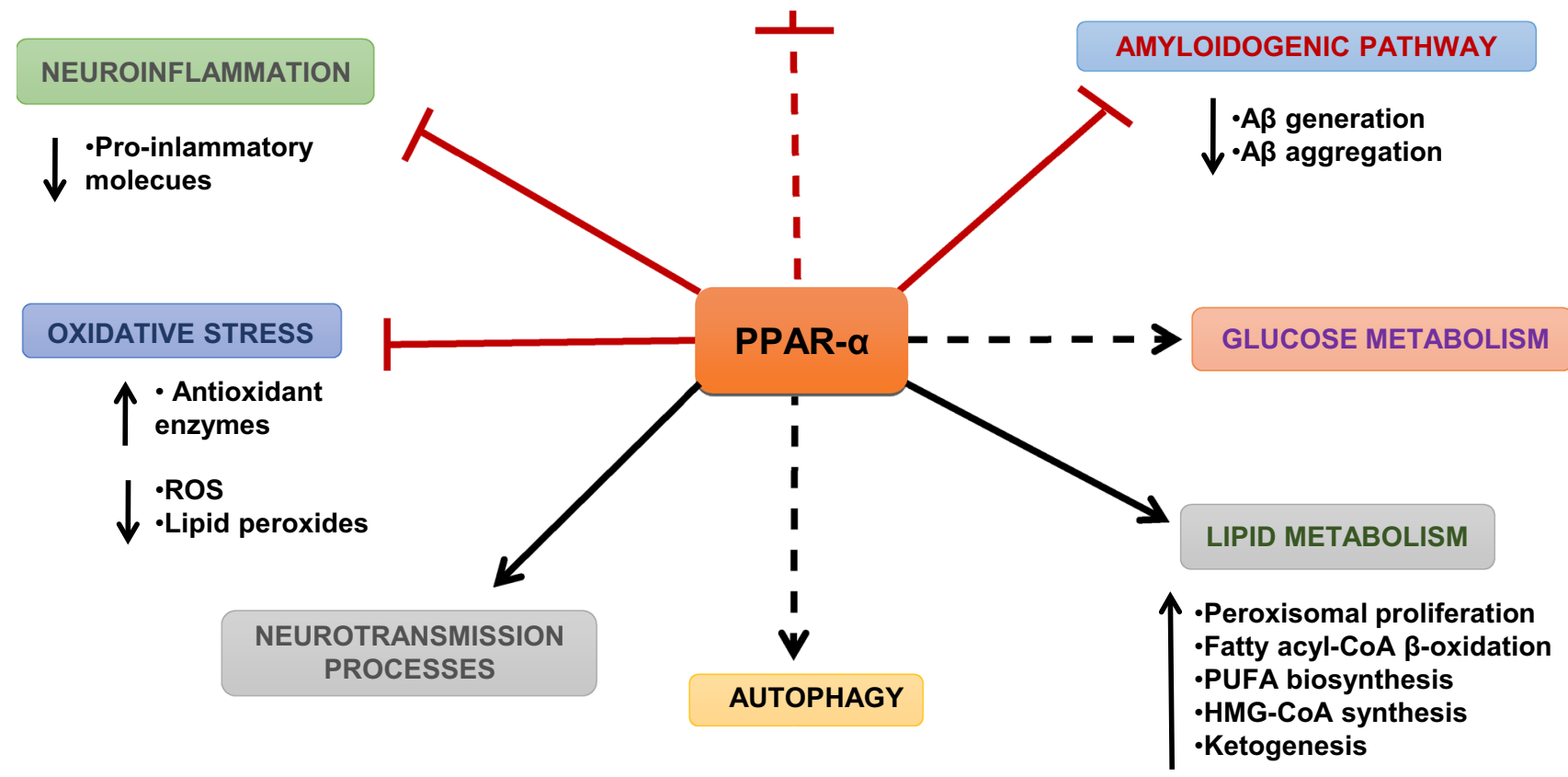

Fig. 1 The role of PPAR- $\alpha$ in the brain (according to D'Orio et al. [136] with some modyfication) 
endocytosis in astrocytes as it was showed by Huang et al. [16]. Astrocytes maintain glutamate homeostasis in CNS by glutamate uptake mediated by aspartate transporter/ excitatory amino acid transporter 1 (GLAST/EAAT1) and glutamate transporter-1/EAAT2 (GLT-1/EAAT2). These two are the most important glutamate transporters in astrocytes, which remove glutamate at the synapses [22]. GLT-1 is responsible for $90 \%$ of forebrain uptake of glutamate in adult CNS and in consequence for glutamate homeostasis in the brain [23]. The imbalance of glutamate homeostasis at glutamatergic synapses could appear when astrocytic GLT-1 expression and function is decreased. It is suggested by Huang et al. [16] that agonist of PPAR- $\alpha$ receptor increases GLT-1 endocytosis in astrocytes through protein kinase C (PKC) signaling pathway. In AD brain the expression and function of PPAR- $\alpha$ is downregulated and may exert the influence on GLT-1 function (Fig. 2). Some other factors may disturb the glutamate homeostasis in AD. For example, alterations of some processes that are engaged in removal of glutamate from synaptic cleft, which can overstimulate postsynaptic glutamate receptor. In the pathological conditions glutamate transporter splice variant AEET2 may reduce glutamate uptake [24]. Moreover, Lauderback et al. [25] indicated that GLT1 could be altered by lipid peroxidation product 4-hydroxy-2-nonenal enhanced by $\mathrm{A} \beta_{42}$. Li et al. [26] suggested several years ago, that abnormal APP expression in AD may be responsible for GLT1 downregulation. PPAR- $\alpha$ agonists (GW7647 and WY14, 643) and treatment with endogenous agonist, palmitic acid (PA) significantly

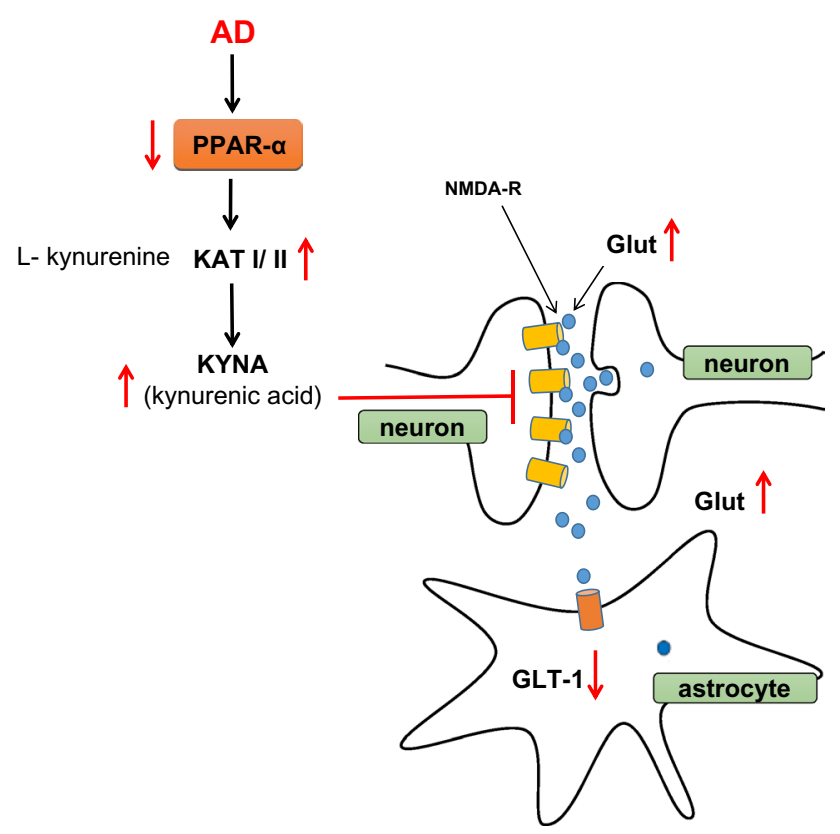

Fig. 2 PPAR- $\alpha$ and it involvement in glutaminergic neurotrasmission and in glutamate homeostasis modulate the level of GLT-1 in astrocytes, with no changes in their morphology [16].

PPAR- $\alpha$ agonist, fibrate exerts neuroprotective effect by regulating the level of kynurenic acid (KYNA) an endogenous glutamate receptor antagonist. KYNA is synthesized in the brain from L-kynurenine (metabolite of L-tryptophan) by kynurenine aminotransferases (KAT) mainly by KATII isoform. An elevated brain concentration of KYNA could be responsible for memory impairment and psychotic symptoms [27, 28]. KYNA and quinolinic acid (QUIN) are major products of tryptophan metabolism, they interact differently with $N$-methyl-D-aspartate receptor (NMDA). KYNA is NMDA antagonist with neuroprotective activity but QUIN is agonist and neurotoxic. Both compounds influence learning and memory [29].

Data of Zakrocka et al. [17, 18], indicated that angiotensin II type 1 receptor blockers and agonist of PPAR- $\alpha$, gemfibrozil, decrease KYNA synthesis in the brain cortex through the inhibitory effect on KATII. Zakrocka also suggested, that in the exact same way PPAR- $\alpha$ may exert beneficial effect in memory and in psychotic disorders. Recently several analogs of KYNA for the treatment of AD were tested and suggested for therapeutic approaches [30]. These all data suggest, that PPAR- $\alpha$ may play an important role in the regulation of glutamate homeostasis, which is known to be crucial in mechanism of learning and memory, in adaptive responses in neuroplasticity and in the course/outcome of several neurological diseases [31-33]. Pierrot et al. [34] reported that PPAR- $\alpha$ is involved in the improvement of hippocampal synaptic plasticity under RXR stimulation in experimental $\mathrm{Tg}$ mice model with cognitive impairment. Activation of PPAR- $\alpha$ receptor with specific receptor agonist enhanced transcription of GluA1 subunits of the alpha-amino-3-hydroxy-5-methyl-4-isoxazolepropionic acid (AMPA), receptor which leads to an AMPA response and better synaptic plasticity upon RXR activation. PPAR- $\alpha$ knockdown in the hippocampus of $\mathrm{AD} \mathrm{Tg}$ cognition-impaired mice eliminated the beneficial effect of RXR activation on synaptic plasticity exclusively in males. The significant role of GluA1 subunit in long term potentiation (LTP) and in cognition was demonstrated by Schmitt et al. [35]. However, Pierrot et al. [34] shows, that LTP improvement in a Tg mouse model of AD upon RXR stimulation is correlated with up-regulation of GluA1 expression and that PPAR- $\alpha$ plays a crucial role in this event in a sex specific manner. The two times higher PPAR- $\alpha$ expression in males versus females could be responsible for the improvement of synaptic plasticity in male cognition-impaired mice by pemafibrate. PPARs and RXR receptors activation upregulates the expression of several synaptic related genes coding proteins engaged in excitatory neurotransmission $[12,36]$. Probably through these mechanism agonists of PPAR- $\alpha$ may have a promising effect in a mouse model of aging-dependent cognitive impairments 
$[37,38]$. Moreover, it was previously reported that RXR activation increases dendritic complexity and branching of neurons and differentiation [39, 40] but it seems now that PPAR- $\alpha$ plays a key role in these processes.

PPAR- $\alpha$ could be also engaged in cholinergic nicotinic receptor regulation of dopaminergic transmission [19, 20]. PPAR- $\alpha$ have been found to decrease nicotine-induced responses of dopamine neurons. Activation of nicotinic acetylcholinergic receptors (AChR) particularly those containing $\beta 2$ subunits significantly regulated activity of dopaminergic neurons. The study of Melis et al. [19] using electrophysiological, biochemical and behavioral methods showed that activation of $\alpha 7-n A c h R$ enhances the $\beta 2$ subunit of $n A C h R s$ and the level of endogenous agonists of PPAR- $\alpha$ in the animal ventral tegmental area (VTA). Their data may indicate the significant role of $n$ AChR/PPAR- $\alpha$ signaling in dopamine neurons. Summarizing it is important to underline that among all PPARs only PPAR- $\alpha$ is involved in regulation of neurotransmission processes in the brain and in memory function. Expression of PPAR- $\alpha$ and PPAR- $\delta$ has been observed to be down regulated in AD [41]. PPAR- $\alpha$ polymorphism may be considered as a risk factor for AD [42]. In several pathological conditions including AD transcription of PPAR- $\alpha$ is regulated in a different way comparing to
PPAR- $\gamma$ [43-46]. Recently it has been observed that PPAR- $\alpha$ plays a significant role in microglia activation in neuroinflammation [47] and its activation evokes cytoprotective effect of statins [10].

\section{The Role PPAR- $a$ in APP/A $\beta$ Metabolism}

PPAR- $\alpha$ receptor plays a significant role in APP metabolism in the brain. The last data of Corbett et al. [48] indicates that under basal physiological conditions PPAR- $\alpha$ is involved in the degradation of APP by activation of APP $\alpha$ secretase leading to liberation of non-amyloidogenic peptide (p3) and soluble sAPP $\alpha$ with possible cytoprotective effect. The activation of this non-amyloidogenic pathway of APP metabolism may protect brain against A $\beta$ liberation through amyloidogenic pathway in which BACE-1 plays a key role (Fig. 3). The authors show that PPAR- $\alpha$ agonist (gemfibrozil), enhances expression of ADAM 10 in hippocampal culture. This observation was confirmed by data on genetically modified animals (with PPAR- $\alpha$ coding gene knockdown). Another study reveals, that agonist of PPAR- $\alpha$ (WY14643) increases ADAM 10 ( $\alpha$ secretase) expression in hippocampal neurons, however neurons lacking PPAR- $\alpha$

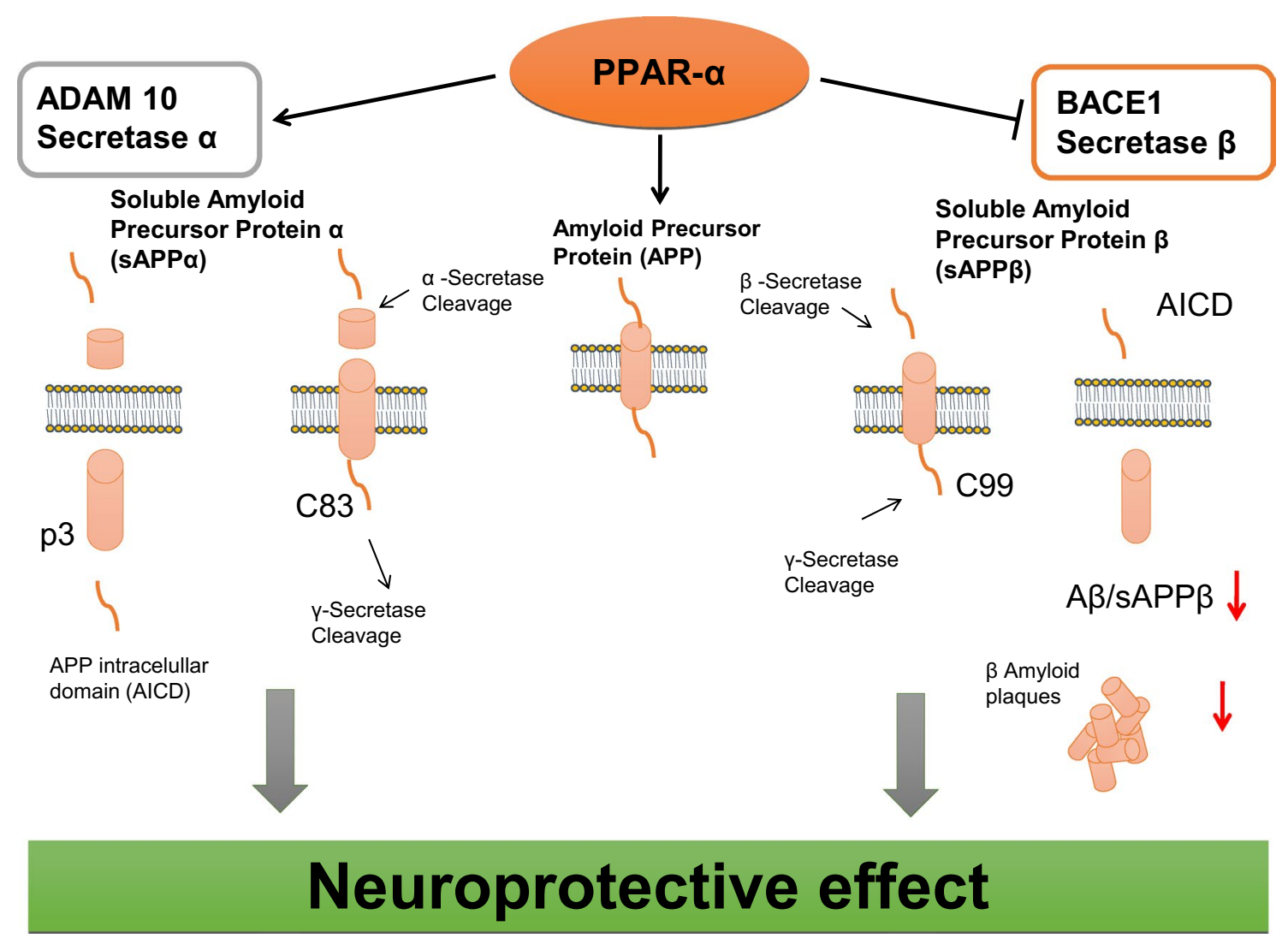

Fig. 3 PPAR- $\alpha$ engagement in regulation of APP secretases in the brain 
coding gene are deficient in ADAM 10 [49]. The other data of Zhang et al. [50] demonstrated, that PPAR- $\alpha$ agonist (GW7647) regulates amyloid $\beta$ (A $\beta$ ) generation by inhibition of BACE-1 activity. Moreover, it was observed that agonist of PPAR- $\alpha$ receptor (GW7647) which decreased the expression of SAPP $\beta$ and the activity of BACE- 1 and $A \beta_{1-42}$ level in cell model of AD had no effect on the level of APP and Preseniline-1 (PS1). Another study of Zhang et al. [51] also showed that phosphatidylinositol 3-kinase (PI3-K) plays a significant role in PPAR signaling leading to reduction of $A \beta$ peptides production. However, in $A D$ alteration of PPAR- $\alpha$ signaling may lead to activation of APP metabolism through amyloidogenic pathway and to $\mathrm{A} \beta$ liberation/ accumulation in the brain. It is possible that $A \beta$ peptides liberated in excessive amount in AD may be responsible for the alteration of PPAR- $\alpha$, closing the vicious circle of pathological events (Fig. 4). Some other data of Kummer et al. [52] have detected that the new PPAR agonist activates all PPARs receptors (GFT1803) decreases significantly $\mathrm{A} \beta$ plaques/A $\beta$ level and microglia activation in $\mathrm{AD}$ mice (APP/PS1). The data suggested the role of these receptors in $A \beta$ degradation or clearance by i.e. enhancement of insulin degrading enzyme (IDE) expression and by its activation. Moreover, pan-PPAR agonist (GFT1803) exerted positive effect on memory function affected in AD mice. Unfortunately, pioglitazone which have been investigated in clinical trial of AD patients have elicited very limited effect. Nowadays PPAR- $\alpha$ seems to be a promising target in AD therapeutic strategy. Anti-amyloidogenic action of PPAR- $\alpha$ agonists (fibrates), was observed in clinic in longitudinal treatment of patients. These people were characterized by lower $\mathrm{A} \beta_{1-42}$ concentration, in comparison to age related, non-treated healthy humans (control group) [53]. The last data published by Chandra et al. [54] and Chandra and Pahan [55] demonstrated that activators of PPAR- $\alpha$ (cinnamic acid and gemfibrozil) decrease amyloid plaque in the hippocampus and cortex in the animal model of AD (5XFAD). Moreover, they decrease neuroinflammation and thus microglia and astrocytes activation and improve spatial learning and cognition function. Activated microglia and astroglia secrete several proinflammatory cytokines and chemokines, some of which, like IL- 1 , TNF- $\alpha$, IL-6, IL-8, and TGF- $\beta$ were observed to have aberrant expression in $\mathrm{AD}$ patients [56].

It is known that the level of $A \beta$ is regulated also by PPAR- $\gamma$ and a number of other transcription factors which have been found to be engage in transcription of gene coding BACE-1. Among these factors some of them play more significant role, like nuclear factor kappa-light-chain-enhancer of activated B cells (NF-кB), stimulatory protein 1 (SP1), yin yang 1 transcription factor (YY1) [57]. Moreover, this study demonstrated that PGC- $1 \alpha$ also participate in regulation of APP $\beta$ secretase, BACE- 1 transcription in vitro and in vivo. Interaction among PPAR- $\gamma /$ PGC- $1 \alpha$ and Sirtuin-1 (SIRT-1) is important in regulation of BACE-1 and is modulated by several environmental conditions including fasting [57].

These three factors interact with PPAR-RXR sites at the promotor of BACE-1 gene. The same group showed that enhancement of PGC- $1 \alpha$ and upregulation of expression of SIRT1 leads to inhibition of BACE-1 gene expression (Fig. 4.). BACE-1 and complex of $\gamma$ secretase are responsible for sequential proteolytic degradation of APP and A $\beta$ peptide liberation, accumulation and the pathogenic protein spread of neurodegeneration in the brain of Alzheimer' patients [58, 59]. Moreover, Qiang et al. [60] showed that SIRT 1 activates PPAR- $\gamma$ directly by deacetylation. The significant role of PPAR- $\gamma /$ PGC- $1 \alpha$ in regulation of Alzheimer's $\beta$ secretase was described by Sweeney and Song [61] and Katsouri et al. [62].

The data of Qin et al. [63] demonstrated that PGC-1 $\alpha$ gene expression is significantly decreased due to progression of clinical dementia in the Alzheimer's brain. Moreover, it was found that PGC- $1 \alpha$ protein content is negatively associated with $A \beta_{1-42}$ amyloid content and $\mathrm{AD}$ type $\mathrm{A} \beta$ plaque pathology. The study on $\operatorname{Tg} 2576 \mathrm{AD}$ mice also indicated correlations between $\mathrm{A} \beta_{1-42}$ level and PGC-1 $\alpha$ expression.
Fig. 4 Inhibition of PPAR- $\alpha$ in AD brain alters APP metabolism

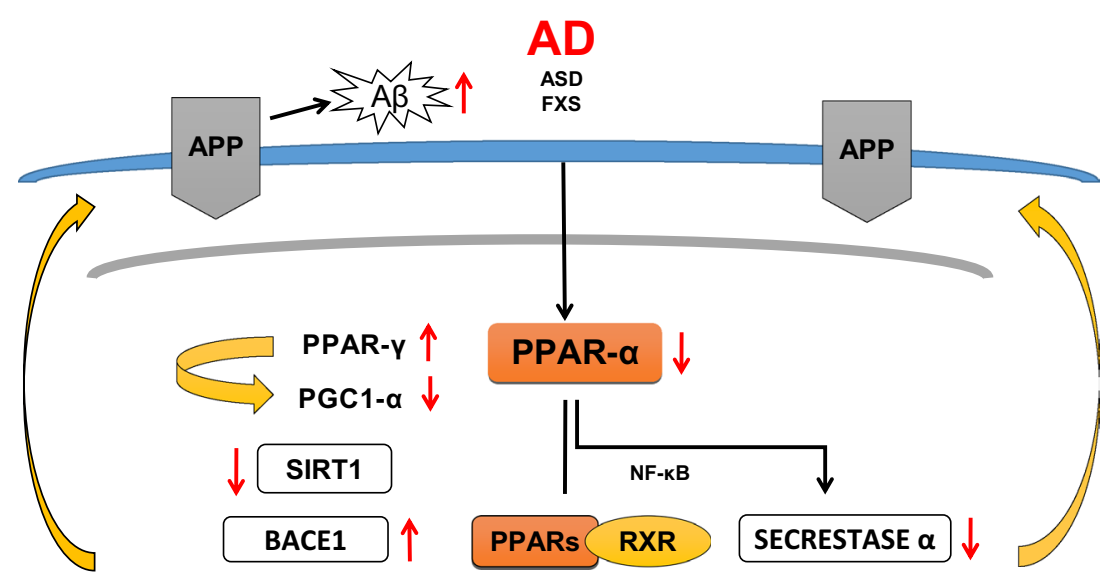


PGC-1 $\alpha$ deficiency causes behavioral changes such as anxiety, hyperactivity and hind limb clasping. Spongiform vacuolization in the striatum and other brain parts was also found [64]. Some other data suggest that PGC-1 $\alpha$ is involved in maintenance of dendritic spines in hippocampal neurons. The authors reported that PGC- $1 \alpha$ overexpression increases dendritic spines and enhances the molecular differentiation of synapses, whereas knockdown of PGC- $1 \alpha$ inhibits synaptogenesis [65]. Figure 3 demonstrates the regulatory role of PPAR- $\alpha$ in physiological conditions on enzymes involved in APP degradation. Activation of PPAR- $\alpha$ induces inhibition of BACE- 1 and suppression of A $\beta$ peptides liberation/accumulation, and concomitant stimulation of $\alpha$ secretase, which is responsible for non amyloidogenic degradation of APP.

The higher level of $A \beta$ observed in the brain of AD and PD patients, in the ischemic brain and the brain that was subjected to traumatic injury is postulated to be responsible for the alterations of neurotransmission processes including glutamatergic and cholinergic transmission connected with changes of PPAR- $\alpha$ signaling and its role in mitochondrial function.

\section{The Role of PPARs in Regulation of Mitochondrial Function}

Mitochondrial disturbances play a crucial role both in aging and in neurodegenerative disorders. Lamichane et al. [66] reported that PPAR- $\alpha$ increases genes expression encoding mitochondrial enzymes that are related to lipid metabolism, which include carnitine palmitylotransferase 1 (CPT1), medium-chain acyl-CoA dehydrogenase, acyl-CoA oxidase and fatty acyl-CoA synthase. Additionally, PPAR- $\alpha$ activates genes coding transport proteins of fatty acids (FA) and their derivatives to allow them enter into the $\beta$-oxidation pathway. PPAR- $\alpha$ induces also expression of gene that encodes protein which transfers acylcarnitine esters in exchange for free carnitine across the mitochondrial membrane [67]. Moreover, PPAR- $\alpha$ together with RXR activates promotor of genes coding malonylCoA dehydrogenase (MLYCD) [68, 69]. PPAR- $\alpha$ activates also nuclear gene encoded pyruvate dehydrogenase kinase 4 (PDK4) which is also activated by PPAR- $\beta / \delta$ but inhibited by PPAR- $\gamma$ [70]. In addition to the PPAR- $\alpha$ other PPARs receptors can be also involved in activation of gene coding acyl-CoA hydrolase enzyme and $\omega$-hydroxylase cytochrome p450 4A subfamily (CYP4A) $[38,71]$. It was found that PPAR- $\alpha$, PPAR- $\gamma$ and its coactivator PGC- $1 \alpha$ are very potent factors in mitochondria biogenesis through activation of mitochondrial transcription
Fig. 5 The role of PPAR- $\alpha$, PPAR- $\gamma$ and PGC1- $\alpha$ on mitochondria biogenesis and function. (according to Dominy and Puigserver [72]; Jornayvaz and Shulman [73]; Scrapulla et al. $[6,8]$ )

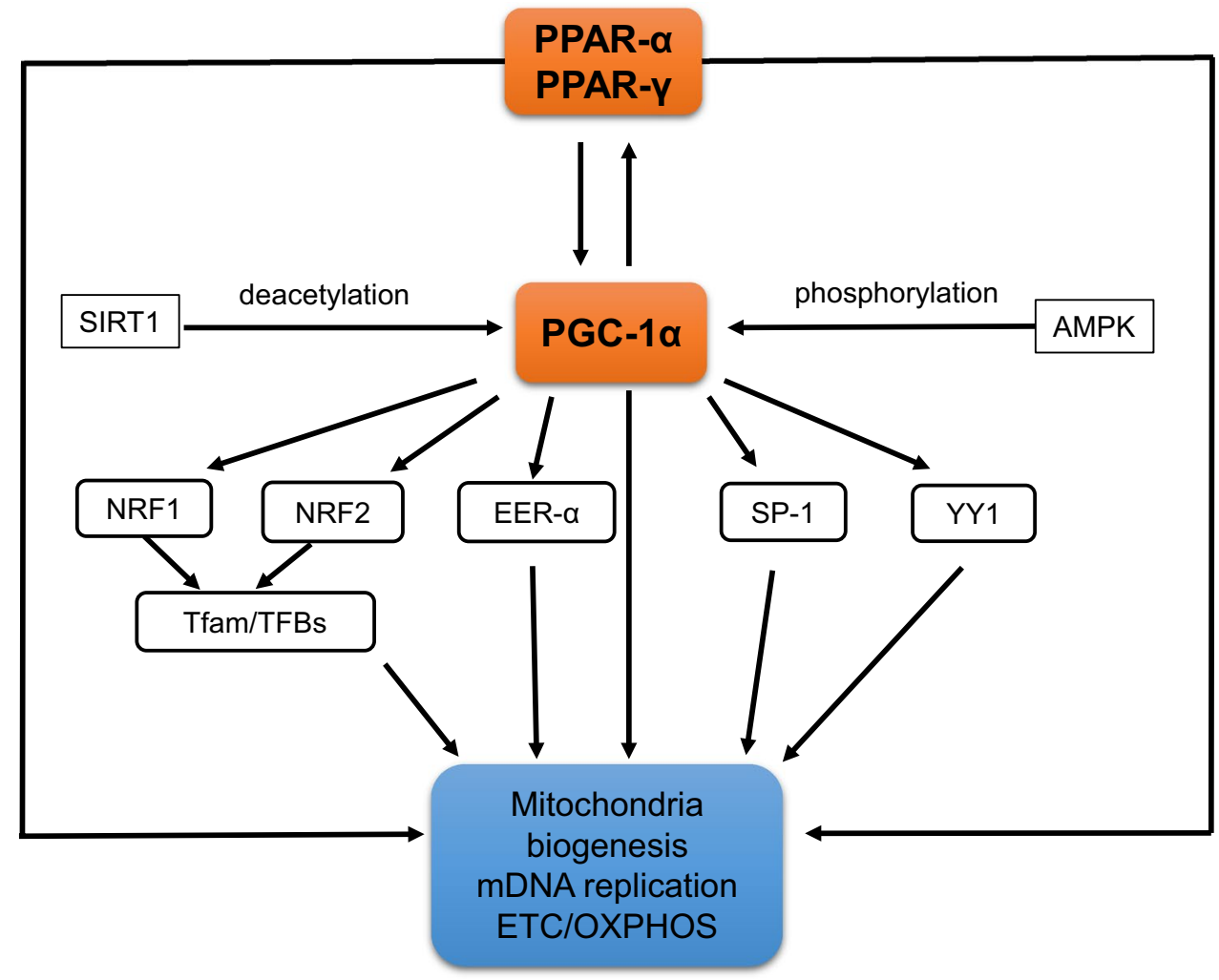


factor and several nuclear transcription factors: (TFAMtranscription factor A mitochondria, NRF1, NRF2, YY1, SP-1) (Fig. 5). Mitochondria biogenesis is regulated by different signaling pathways and transcriptional complexes that activate the formation and assembly of mitochondria $[4,6$, $8,9,72,73]$.

It is well known, that mitochondria are under significant, direct control of the nucleus. The majority of mitochondrial proteins are encoded by nuclear DNA (nDNA) similar to all nuclear transcription factors and other proteins and enzymes, including Sirtuins, poly (ADP-ribose) polymerases (PARPs) [72, 74-76]. Additionally, some of these proteins as PARP-1 are involved in DNA repair and in synthesis of Poly (ADP-ribose), (PAR) the signaling molecule that is engaged in nucleus -mitochondria crosstalk [77]. Huang et al. [16] identified PPAR- $\alpha$ as a substrate of PARP-1. This NAD dependent, DNA bound enzyme, is a key mediator of stress response, cells survival and death and molecular regulator of several transcription factors and other proteins. The data of Bai et al. [78] showed that PARP-1 inhibition exerts significant metabolic effect through the activation of Sirt1. Lapucci et al. [79] indicated that PARP-1 plays a key role in mitochondria homeostasis by epigenetically regulating nuclear genes involved in mtDNA repair and transcription. Nevertheless, mitochondria contain their own genome and also PARP-1 which could be involve in repair of mitochondrial DNA (mDNA) and in regulation of mitochondrial energy processes $[80,81]$. It is well known that mDNA is responsible for encoding of 13 polypeptides, the subunits of respiratory Complexes I, III, IV and V as well as 2 rRNAs and 22 tRNAs [82]. The other proteins as subunits of respiratory complex II and proteins required for mDNA replication, transcription and translation and all other factors engaged in regulations of these processes are encoded by nucleus [83]. A relatively small number of nuclear factors coordinate the transcription of all respiratory proteins. Among TF are these mentioned above nuclear respiratory factors: NRF1, NRF2 then SP1, YY1 and estrogen related receptor alpha (ERR$\alpha)$. Moreover, the latest data indicated presence of NAD dependent enzymes in mitochondria as PARP-1, SIRT-1 and the other Sirtuins, as SIRT-3, SIRT-4, SIRT-5, which could be involved in post translational modifications of many TF and other proteins by deacetylation, poly and mono ADPribosylation, sumoylation etc. $[74,75]$.

Numbers of components of the regulatory network proteins, such as nuclear receptor superfamily, PPARs and also DNA bound PARPs and nucleus located histone deacetylases type III, Sirtuins (SIRT-1 and SIRT-6) are implicated in mitochondria dynamics and function and may play a significant role in onset and progression of neurodegenerative diseases [75]. It is now commonly presumed, that inflammation is significantly involved in genesis and progression of most of neurological and metabolic diseases. It seems that
PPAR- $\alpha$, PGC- $1 \alpha$ and the other family of nuclear receptors could be promising targets in therapeutic strategy [84].

Each of nuclear receptors PPARs has specific functions as it was described above. PPAR- $\alpha$ regulates oxidative stress, energy homeostasis, mitochondrial fatty acids metabolism and it may also influence excitatory glutamatergic neurotransmission and probably also cholinergic/dopaminergic signaling in brain. PPAR- $\beta / \delta$ and PPAR- $\gamma$ regulates mainly lipids metabolism, but their specific role in the brain is yet not fully elucidated $[85,86]$. There are some data demonstrated the role of PPAR- $\beta$ in myelination processes in CNS [87].

PGC- $1 \alpha$ through interaction with several nuclear receptors including PPARs can be involved in transcription regulation of genes that are related to neuro-inflammation, neuroapoptosis and anti-oxidative defense. Moreover, PGC- $1 \alpha$ may play a significant role in the regulation of expression of genes that are coding proteins engaged in mitochondria biogenesis, DNA level and mitochondria function [73]. PGC- $1 \alpha$ may regulate mitochondria oxidative metabolism by activating genes that are involved in the tricarboxylic acid cycle (TCA), oxidative phosphorylation, $\beta$-oxidation of fatty acids [88]. PPARs are involved in activation of PGC- $1 \alpha$ expression, which subsequently plays an important role as coactivator of these receptors and regulator of PPARs transcription. These relationships may lead to some type of molecular vicious circle. PGC- $1 \alpha$ is activated by NAD regulated enzymes, by SIRT-1 mediated deacetylation, or by phosphorylation mediated by $5^{\prime}$ adenosine monophosphateactivated protein kinase (AMPK) and other kinases. p38 [64]. It was observed that gene expression and protein level of PGC- $1 \alpha$ dependently on pathological conditions of CNS could be differently affected. There are several data reporting down regulation of PGC- $1 \alpha$ expression and activity in $\mathrm{AD}$ and in the other pathological conditions as Huntington disease (HD) brain ischemia and inflammation [52, 57].

Patients with Huntington's disease (HD) had a decreased level of PGC- $1 \alpha[89,90]$ which may suggest that PGC- $1 \alpha$ is crucial for striatal cells function. In Parkinson Disease (PD) mouse model, PGC- $1 \alpha$ deficiency is suggested to be involved in degeneration of dopaminergic neurons in the substantia nigra. The protective role of PGC- $1 \alpha$ was demonstrated in Amyotrophic Lateral Sclerosis (ALS) mice and ALS patients by Thau et al. [91].

Recently it is also suggested, that PGC- $1 \alpha$ plays a significant role in brain ischemic encephalopathy, hepatic encephalopathy, brain alterations in diabetes type I and diabetes type II and in neurodegenerative processes evoked by acute and chronic brain injury which may lead to traumatic encephalopathy $[64,92]$. PGC- $1 \alpha$ synthesis is regulated by changes in environmental conditions and it is believed that this factor can link signal from the environment to gene expression in the brain. PGC- $1 \alpha$ is expressed in all brain tissue and 
in most brain regions and plays a key role in the oxidative stress response [92, 93]. Mechanism of neuroprotection mediated by PGC- $1 \alpha$ signaling pathway is very complex as it was demonstrated recently by Lv et al. [92]. Summarizing PGC- $1 \alpha$ has an influence on cellular metabolism and inflammatory response through regulation of mitochondrial biogenesis, oxidative metabolism, fatty acid oxidation and gluconeogenesis in mechanism dependent on PPARs function. PGC- $1 \alpha$ is also able to regulate not only PPARs but also other nuclear receptors, such as estrogen receptors. Despite the growing number of reports on the role of PGC- $1 \alpha$ in neuroprotection, the mechanism of PGC- $1 \alpha$ in regulation of gene expression and mitochondria dynamic and function in different pathological conditions is not fully elucidated.

\section{PPAR-a Natural and Synthetic Agonists: from Experiments to Clinical Trials}

PPAR- $\alpha$ regulates oxidative stress, energy homeostasis, mitochondrial fatty acids metabolism and is only one among all PPARs which influence excitatory glutamatergic neurotransmission and also cholinergic/dopaminergic signaling in the brain. Expression of PPAR- $\alpha$ but also other PARPs is significant in prefrontal cortex, nucleus accumbens and amygdala in the brain and significantly higher in neuronal cells versus glia cells [11].

The specific role of PPAR- $\beta / \delta$ and PPAR- $\gamma$ in the brain is yet not fully elucidated $[85,86]$. There are some data demonstrating the involvement of PPAR- $\beta$ in myelination processes in CNS [87]. On the basis of data, it is now expected that activation of PPAR- $\alpha$ should be most promising in therapeutic strategy of several neurodegenerative and metabolic disorders.

The data of Esmaeili et al. [84] demonstrated, that preferential activation of PPAR- $\alpha$ by fenofibrate reduces neuroinflammation and blocks neurodegeneration in mice model of ALS. In animals treated with fenofibrate, the mRNA analysis indicated significant effect of this drug on transcription of genes that encode proteins engaged in anti-inflammatory and anti-oxidative defense. It also down regulates expression of genes that are involved in neuro-inflammation. In PD animals model treated with agonist of PPAR- $\alpha$, mitochondria were preserved and treated mice exhibited enhanced motor performance. Fenofibrate treatment significantly delayed progression of disease.

In other experimental animal model, that was part of the study on PD, Uppalapati et al. [94] was also observed neuroprotective effect of PPAR- $\alpha$ agonist, fenofibrate/fenofibric acid. This compound exerted significant ameliorating effect on cognitive impairment. About $40 \%$ of PD patients are affected with cognitive impairment and dementia, which are about 6 times more frequent in PD patient comparing to healthy, age related control people. Several previous studies indicated promising effects of PPAR agonists in PD [95-98]. Previously also Carta et al. [99] reported ameliorating effect of rosiglitazone which decreased PPAR- $\gamma$ level and inhibited $\mathrm{TNF} \alpha$ production in progressive PD mice model. Another randomized trial of pioglitazone did not confirm the ameliorating effect of this drug in PD [4]. A significant effect of PPAR agonists was observed in treatments of depressive states which often occur also in prodromal stage of PD being therefore considered as a very important early symptom of PD. Further investigations are necessary to evaluate the role of PPARs in PD.

The study of the last decade indicated the important role of PPAR- $\alpha$ in cognition and emotions [100]. Their data underline the relationship between function of PPAR- $\alpha$, its endogenous agonists and the level of neurosteroids in stress conditions. PPAR- $\alpha$ is high in these brain regions which participate in the regulation of emotions and stress response.

The highest expression of PPAR- $\alpha$ was found in prefrontal cortex, basal ganglia, amygdala, and in thalamic nuclei, but its expression is way lower in hippocampus [11]. The data of Nisbett and Pinna [100] demonstrated that PPAR- $\alpha$ activation mediate and modulate stress response observed also by Hillard [101]. It was proposed that in the mechanism of PPAR- $\alpha$ action on emotion and stress key role may play neurosteroids such as allopregnanolone/prognanolone [102]. Basing on the correlation between PPAR- $\alpha$ stimulation and allopregnanolone biosynthesis the novel biomarker axis and therapeutic strategy is proposed for emotional alterations observed in posttraumatic stress disorders (PTSD) and other mood disorders [100]. Agonist of PPAR- $\alpha$ receptor may exert neuroprotective effect also by enhancing the level of brain derived neurotrophic factor (BDNF). Jiang et al. [103] reported antidepressant-like effect of fenofibrate in mice via PPAR- $\alpha$ mediated BDNF signaling pathway in hippocampus. The antidepressive-like effect of fenofibrate in the mice model was blocked by PPAR- $\alpha$ inhibitor and lower hippocampal BDNF signaling pathway. Moreover, the same group [103] postulated that the antidepressant-like effect of fenofibrate do not require the cannabinoid system. Several studies supported the crucial role of BDNF signaling alterations in pathophysiology of depression [104, 105]. Previously it was observed that pioglitazone significantly improves depressive symptoms and significantly reduces the level of pro-inflammatory cytokines in bipolar disorder as reported by Kemp et al. [106] and Zeinoddini et al. [107]. Improvements of depression severity were also observed in unipolar depression by Kemp et al. [108, 109] as well as by Lin et al. [110] in double-blind placebo-controlled trial.

On the basis of actual data PPAR- $\alpha$ and PPAR- $\gamma$ receptor agonist and also PGC- $1 \alpha$ are further proposed as a promising target in therapy of metabolic and inflammatory disorders as well as other neurological and neuropsychiatric diseases. 
In several neurodegenerative diseases PGC- $1 \alpha$ expression is downregulated together with its target genes that code NRF1 and TFAM. This data suggested that signaling pathway mediated by these proteins is crucial in neurodegeneration/ neuroprotection. PGC- $1 \alpha$ and PPARs are important in adaptive responses of neuronal mitochondria to bioenergetics challenges [32]. Moreover, it is important to underline that PGC- $1 \alpha$ negatively regulates extra synaptic glutamatergic receptor (NMDAR) activity and excitotoxicity [111]. The studies of Vallee and Lecarpentier [49] on AD described that PPAR- $\gamma$ agonists diminish learning and memory deficit in $\mathrm{AD}$ patients.

Recently few clinical trials indicated and suggested that PGC- $1 \alpha$ through its interaction with PPARs could have promising effects in a therapy of mood alterations, particularly in the treatment of depressed states. Sepanjnia et al. [112] reported that pioglitazone therapy improved the mood in depressive episodes. The mechanism of antidepressive action of the pioglitazone should be better elucidated. Changes in the level of several endogenous ligands of PPAR- $\gamma$ including fatty acids and prostaglandins may exert additional effect on the signaling pathway.

The endogenous compounds are weak agonists and a role of its interactions with PPARs receptors in physiological and pathological conditions is not fully understood. Several compounds were synthesized, among them thiazolidinediones (also called glitazones), which are strong agonists. These compounds were studied in many diseases and were used in clinical treatment of obesity and other metabolic disorders. Up till now rosiglitazone (BRL-49653) and pioglitazone were recommended for diabetic type II treatment. Most of compounds from this group of drugs including rosiglitazone were removed from the USA market by FDA due to their dangerous side effects like increase the risk of myocardial infraction [113].

Recent study indicated that PGC- $1 \alpha$ and agonists of pan-PPARs may play an important role in autism spectrum disorder and other neuropsychiatric alterations [114]. It was indicated that agonists of PPAR- $\alpha$ and also all PPARs could be involved in the bipolar disorders and in depression [4]. They also have an influence on behavioral repetition and cognitive flexibility in mice [115]. Additionally, the protective effect of PPAR- $\alpha$ agonist was showed in rat model of oral dyskinesia and in different types of encephalopathy $[116,117]$. Moreover, PPARs agonists may also affect alcohol consumption behavior [118]. There are several data indicating, that neuroprotective effect of PPAR- $\alpha$ mediate the action of resveratrol against stroke which is similar as the effect of fenofibrate [119]. PPAR- $\alpha$ receptor stimulation induces synthesis of allopregnanolone in astrocytes and this hormone might be involved in neuroprotective mechanism [120]. Therapeutic effect of PPAR- $\alpha$ on neuronal death and microvascular impairment was described by Moran and
Ma [121]. PPAR- $\alpha$ and other receptors from this family play significant role in regulation of oxidative stress and inflammatory reactions. It is now accepted, that oxidative stress is considered to be a crucial factor in pathogenesis and pathomechanism of neurodegenerative and neurodevelopmental/psychiatric disorders. Recently mitochondrial oxidative stress is believed to be associated with autism spectrum disorders (ASD), which is frequently diagnosed among children. This disorder is induced by genetic/chromosomal abnormalities and environmental factors, which could include prenatal exposure to stress, altered hormone levels or different teratogenic compounds. This multi-factors disorder, ASD, is now observed in as many as 1 in 80 children, or even 1 in 41 children and the proper therapy has not been yet discovered. It was observed and suggested, that alteration of presynaptic proteins, including APP, that till now were mostly investigated in relation to $\mathrm{AD}$, occurs also in ASD. APP is known to play a very important role in synaptogenesis, in neurite outgrowth, in integrity of brain development, memory formation and in neuronal plasticity. Unfortunately, its expression and degradation is significantly affected in the brain of ASD. Amadei et al. [122] reported, that $\beta$ amyloid plaques occur also in the brain of children with ASD. Additionally, elevated level of soluble sAPP $\alpha$ was detected earlier in the blood of autistic children. It was observed, that agonist of PPARs, pioglitazone, GFT1803 (Pan-PPAR agonist), protects brain against amyloid $\beta$ deposition and cognition impairment [52].

The two neurodevelopmental disorders-ASD and Fragile X Syndrome (FXS) are connected with altered APP metabolism and with $\mathrm{A} \beta$ plaque formation, which may affect learning and memory function. It is suggested, that sAPP, $A \beta_{1-42}$, Tau protein and also ApoE allele should be considered as a promising biomarkers not only for $\mathrm{AD}$ but also for ASD and perhaps other neurodevelopmental disorders. Several data indicated that PPARs/PGC- $1 \alpha$ and SIRT- 1 are involved in regulation of BACE-1 transcription, the key enzyme for $A \beta$ generation. Data of Wang et al. [57] demonstrated that BACE-1 promotor contains multiple PPAR-RXR sites. Previous results indicated, that BACE-1 expression is regulated significantly by several transcription factors in $\mathrm{AD}$ and in ASD and inflammation by NF- $\mathrm{KB}$ and PPAR [123, 124].

The pathogenesis/pathomechanism of neurodegenerative diseases is not yet elucidated and therapy is not successful. Several pharmacological compounds including PPARs agonists were applied in the treatment of patients with ASD, AD, PD, ASL, however many side effects of PPARs agonists were observed and described recently [4].

Nowadays there are novel research directions exploring the potential of PPAR- $\alpha$ agonists including natural and synthetic compounds as demonstrated in Tables 1 and 2 respectively. Moreover, some studies are directed to find 
Table 1 Agonists of PPAR- $\alpha$ - natural and synthetic (according to data published by Adedapo et al. [127]; Singh et al. [128]; Rigano et al. 2017 [129]; and Contreas et al. [130], Fournier et al. [2])

\section{PPAR- $\alpha$ agonist}

\begin{tabular}{|c|c|c|c|}
\hline \multicolumn{3}{|l|}{ Natural } & \multirow[t]{2}{*}{ Synthetic } \\
\hline Endogenous & Exogenous & & \\
\hline Oleoylethanolamine (OEA) & Monoterpenes & Linalool & $\begin{array}{l}\text { 2-(4-Chlorophenoxy)-2-methyl-propanoic acid, ethyl } \\
\text { ester Clofibrate }\end{array}$ \\
\hline Palmitoylethanolamide (PEA) & $\begin{array}{l}\text { Sesqui } \\
\text { terpenes }\end{array}$ & Trans caryophyllene & $\begin{array}{l}\text { 2-[4-[2-[(4-Chlorobenzoyl)amino]ethyl]phenoxy]- } \\
\text { 2-methylpropanoic acid Bezafibrate }\end{array}$ \\
\hline $\begin{array}{l}\text { 8-hydroxyeicosatetraenoic acid (8 }(\mathbf{s}) \\
\text { HETE) }\end{array}$ & & Farnesol & $\begin{array}{l}\text { Propan-2-yl 2-[4-(4-chlorobenzoyl)phenoxy]-2-meth- } \\
\text { ylpropanoate Fenofibrate }\end{array}$ \\
\hline $\begin{array}{l}\text { 8-hydroxyeicosapentaenoic acid }(\mathbf{8}(\mathbf{s}) \\
\text { HEPE) }\end{array}$ & Diterpenes & Phytol & $\begin{array}{l}\text { (5-(2,5-Dimethylphenoxy)-2,2-dimethylpentanoic } \\
\text { acid) Gemfibrozil }\end{array}$ \\
\hline \multirow{2}{*}{$\begin{array}{l}\text { Arachidonic acid (ARA) } \\
\text { (C20:4) }\end{array}$} & Triterpenes & Oleanolic acid & \\
\hline & Anthraquones & Norathyriol & $\begin{array}{l}\text { (2-(4-(2-(1-Cyclohexanebutyl)-3-cyclohexylureido) } \\
\text { ethyl)phenylthio)-2-methylpropionic acid) GW } \\
\mathbf{7 6 4 7}\end{array}$ \\
\hline Leukotriene B4 & \multirow[t]{2}{*}{ Pnenylopro panoids } & Rosmarinic acid & $\begin{array}{l}\text { (2-[[4-[2-[[[(2,4-Difluorophenyl)amino]carbonyl] } \\
\text { heptylamino]ethyl]phenyl]thio]-2-methyl-propanoic } \\
\text { acid) } \mathbf{G W} 9578\end{array}$ \\
\hline $\begin{array}{l}\text { Eicosapentaenoic acid (EPA) } \\
(\mathbf{C 2 0 : 5})\end{array}$ & & Verbascoside & $\begin{array}{l}\text { 2-Methyl-2-[4-[3-[1-[(4-methylphenyl)methyl]-5- } \\
\text { oxo-2H-1,2,4-triazol-3-yl]propyl]phenoxy]propa- } \\
\text { noic acid LY 518674 }\end{array}$ \\
\hline $\begin{array}{l}\text { Linoleic acid (LA) } \\
(\text { C18:2) }\end{array}$ & Coumarins & Coumarin & $\begin{array}{l}\text { 2,2-Dichloro-12-(4-chlorophenyl)dodecanoic acid } \mathbf{K} \\
\mathbf{1 1 1}\end{array}$ \\
\hline $\begin{array}{l}\text { Palmitic acid (PA) } \\
\text { (C16:0) }\end{array}$ & Lignans & Sesamin & $\begin{array}{l}\text { (S)-3-[3-(1-carboxy-1-methyl-ethoxy)-phenyl]-piperi- } \\
\text { dine-1-carboxylic acid CP } 900691\end{array}$ \\
\hline \multirow[t]{8}{*}{$\begin{array}{l}\text { Stearic acid }(\mathbf{S A}) \\
(\mathbf{C 1 8 : 0})\end{array}$} & $\begin{array}{l}\text { Polyphenoles } \\
\text { Flavonoides }\end{array}$ & $\begin{array}{l}\text { Pterostilbene } \\
\text { Hispidulin }\end{array}$ & $\begin{array}{l}\text { 4-Chloro-6-(2,3-xylidino)-2-pyrimidinylthioacetic } \\
\text { acid, Pirinixic acid WY } \mathbf{1 4 6 4 3}\end{array}$ \\
\hline & & $\begin{array}{l}\text { Wagonin } \\
\text { Epigallocatechin }\end{array}$ & \multirow[t]{7}{*}{$\begin{array}{l}\text { 2-Methyl-c-5-[4-[5-methyl-2-(4-methylphenyl)-4- } \\
\text { oxazolyl] butyl]-1,3-dioxane-r-2-carboxylic acid } \\
\text { (NS 220) }\end{array}$} \\
\hline & Isoflavonoids & $\begin{array}{l}\text { Genistein } \\
\text { Daidzein } \\
\text { Biochanin A } \\
\text { Formononetin } \\
\text { Tectoridin }\end{array}$ & \\
\hline & Bioflavonoids & Bilobetin & \\
\hline & Alkaloids & Picrasidine $\mathrm{C}$ & \\
\hline & & Berberine & \\
\hline & & Oxymatrine & \\
\hline & & Capsaicin & \\
\hline
\end{tabular}

novel promising dual and pan PARPs agonists for treatments of inflammatory and neurodegenerative disorders. The pan PPAR agonist, bezafibrate is used with success for over 25 years in the treatment of patients with metabolic syndrome, DM-TII, in antycholesterolemia strategy and in protection against myocardial disorders [125]. Bezafibrates have positive effects on mitochondria function and on behavior in PD and HD [64, 126]. Their action trough three receptors types may lead to the elimination of negative influences of PPAR- $\gamma$ on cardiovascular system, metabolic rate and body weight. Unfortunately, a lot of clinical trials with agonists of PPARs in neurodegenerative diseases are controversial, due to the fact, that there are studies suggesting their ineffectiveness. Some other last data indicate promising, positive effect of PPARs agonists [127-135]. Overall it seems that personalized gene-related therapy or personalized combination 


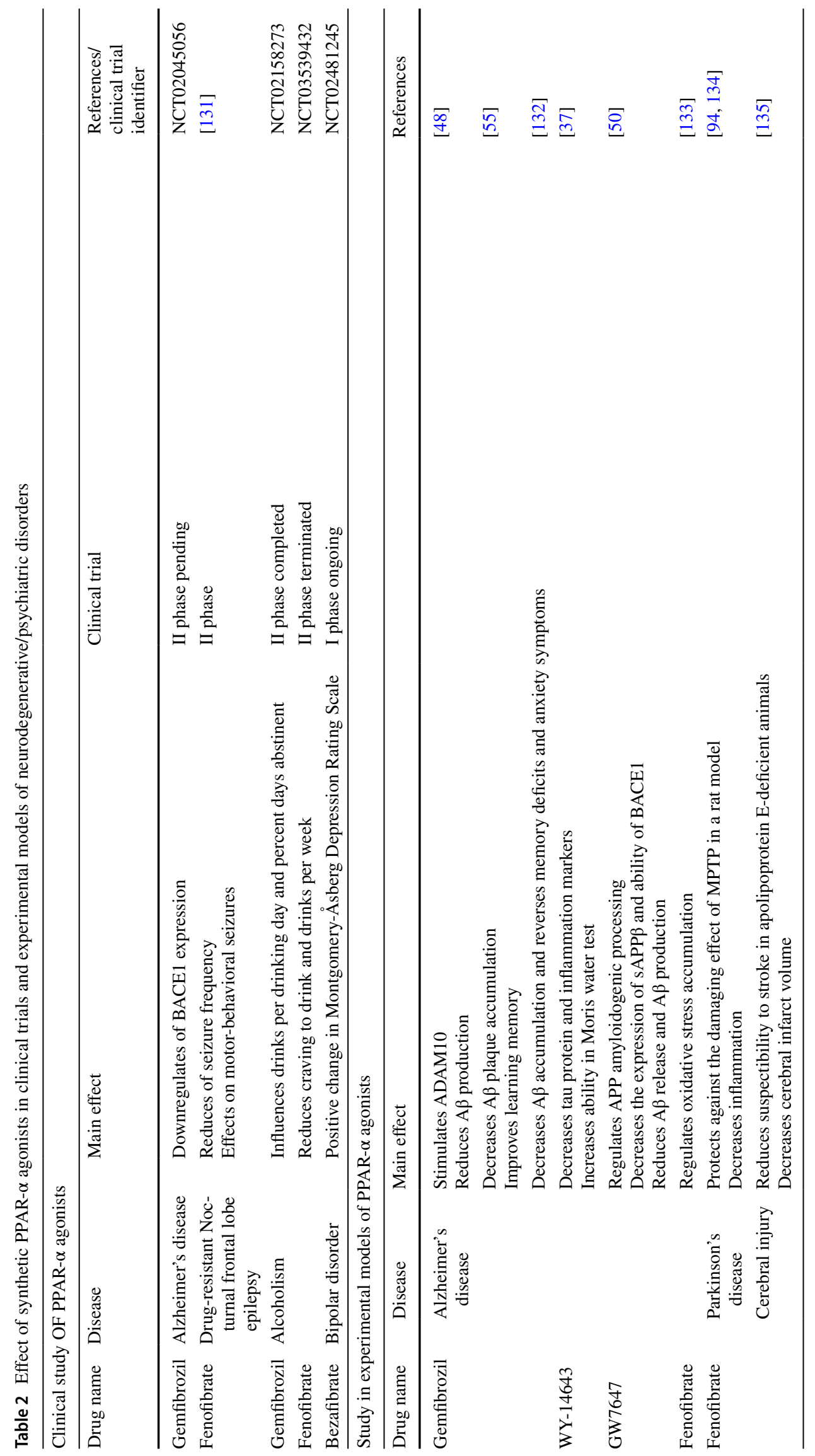


of specific pharmacological compounds should be more efficient. The further studies on pharmacologically active compounds that target PGC- $1 \alpha$ and PPARs are necessary.

\section{Summarizing}

This review focused on the role of PPAR- $\alpha$ and it interaction with PPAR- $\gamma /$ PGC- $1 \alpha$ in the brain during neurodegenerative and neuropsychiatric disorders. PPAR- $\alpha$ is involved in regulation of glutamate homeostasis and in some aspects also in cholinergic and dopaminergic signaling. Only PPAR- $\alpha$ receptor plays a significant role in transcription of genes coding proteins that are engaged in neurotransmission processes in the brain. However, further studies are necessary to understand the role of PPAR- $\alpha$ in glutamatergic and other signaling pathways in physiological conditions and in AD or other neurodegenerative/neurodevelopmental diseases.

The recent data demonstrated, that PPAR- $\alpha$ is engaged in APP metabolism through amyloidogenic pathway. PPAR- $\alpha$ activates $\alpha$ secretase and inhibits BACE-1, the key enzyme responsible for $\mathrm{A} \beta$ peptides liberation. However, nothing is known on its role on $\mathrm{A} \beta$ peptides transport and on mechanism of it degradation in AD.

In AD, PPAR- $\alpha$ opposite to PPAR- $\gamma$ is down regulated similar to PGC- $1 \alpha$, however the mechanism of the PPAR- $\alpha$ signaling alterations in AD hasn't been fully elucidated yet.

In mitochondria PPAR- $\alpha$ is involved in regulation of fatty acid and energy metabolism. However, its significance in regulation of mitochondria biogenesis, dynamics and function of electron transport complexes as well as the effect of fenofibrates, agonists of this receptor used for many years in therapy of diabetes type II, obesity and other metabolic disorders hasn't been fully analyzed up till now. It seems now that PPAR- $\alpha$ could be promising target for the novel therapeutic strategy of AD and other neurodegenerative and neurodevelopmental disorders. However, the mechanism of its action in the brain should be characterized in depth to enable successful application.

Acknowledgements Supported by Statute Theme No 5 and POWER Och!Dok

\section{Compliance with Ethical Standards}

Conflict of interest All authors have nothing to disclose.

Open Access This article is licensed under a Creative Commons Attribution 4.0 International License, which permits use, sharing, adaptation, distribution and reproduction in any medium or format, as long as you give appropriate credit to the original author(s) and the source, provide a link to the Creative Commons licence, and indicate if changes were made. The images or other third party material in this article are included in the article's Creative Commons licence, unless indicated otherwise in a credit line to the material. If material is not included in the article's Creative Commons licence and your intended use is not permitted by statutory regulation or exceeds the permitted use, you will need to obtain permission directly from the copyright holder. To view a copy of this licence, visit http://creativecommons.org/licenses/by/4.0/.

\section{References}

1. Borel V, Gallot D, Marceau G, Sapin V, Blanchon L (2008) Placental implications of peroxisome proliferator-activated receptors in gestation and parturition. PPAR Res 2008:758562-758562. https://doi.org/10.1155/2008/758562

2. Fournier T, Tsatsaris V, Handschuh K, Evain-Brion D (2007) PPARs and the Placenta. Placenta 28(2):65-76. https://doi. org/10.1016/j.placenta.2006.04.009

3. Berger J, Moller DE (2002) The mechanisms of action of PPARs. Annu Rev Med 53(1):409-435. https://doi.org/10.1146/annur ev.med.53.082901.104018

4. Nierenberg AA, Ghaznavi SA, Sande Mathias I, Ellard KK, Janos JA, Sylvia LG (2018) Peroxisome proliferator-activated receptor gamma coactivator-1 alpha as a novel target for bipolar disorder and other neuropsychiatric disorders. Biol Psychiatry 83(9):761-769. https://doi.org/10.1016/j.biopsych.2017.12.014

5. Issemann I, Green S (1990) Activation of a member of the steroid hormone receptor superfamily by peroxisome proliferators. Nature 347(6294):645-650. https://doi.org/10.1038/347645a0

6. Scarpulla RC, Vega RB, Kelly DP (2012) Transcriptional integration of mitochondrial biogenesis. Trends Endocrinol Metab 23(9):459-466. https://doi.org/10.1016/j.tem.2012.06.006

7. D'Angelo M, Antonosante A, Castelli V, Catanesi M, Moorthy N, Iannotta D, Cimini A, Benedetti E (2018) PPARs and energy metabolism adaptation during neurogenesis and neuronal maturation. Int J Mol Sci 19(7):1869. https://doi. org/10.3390/ijms19071869

8. Scarpulla RC (2011) Metabolic control of mitochondrial biogenesis through the PGC-1 family regulatory network. Biochim Biophys Acta 1813(7):1269-1278. https://doi.org/10.1016/j. bbamcr.2010.09.019

9. Austin S, St-Pierre J (2012) PGC1 $\alpha$ and mitochondrial metabolism-emerging concepts and relevance in ageing and neurodegenerative disorders. J Cell Sci 125(21):4963-4971. https://doi. org/10.1242/jcs. 113662

10. Benedetti E, Cristiano L, Antonosante A, D’Angelo M, D'Angelo B, Selli S, Castelli V, Ippoliti R, Giordano A, Cimini A (2017) PPARs in neurodegenerative and neuroinflammatory pathways. Curr Alzheimer Res. https://doi.org/10.2174/156720501466617 0517150037

11. Warden A, Truitt J, Merriman M, Ponomareva O, Jameson K, Ferguson LB, Mayfield RD, Harris RA (2016) Localization of PPAR isotypes in the adult mouse and human brain. Sci Rep 6:27618-27618. https://doi.org/10.1038/srep27618

12. Roy A, Jana M, Corbett GT, Ramaswamy S, Kordower JH, Gonzalez FJ, Pahan K (2013) Regulation of cyclic AMP response element binding and hippocampal plasticity-related genes by peroxisome proliferator-activated receptor $\alpha$. Cell Rep 4(4):724-737. https://doi.org/10.1016/j.celrep.2013.07.028

13. Sakimura K, Kutsuwada T, Ito I, Manabe T, Takayama C, Kushiya E, Yagi T, Aizawa S, Inoue Y, Sugiyama H, Mishina M (1995) Reduced hippocampal LTP and spatial learning in mice lacking NMDA receptor $\varepsilon 1$ subunit. Nature 373(6510):151-155. https://doi.org/10.1038/373151a0

14. Lee H-K, Takamiya K, Han J-S, Man H-Y, Kim C-H, Rumbaugh G, Yu S, Ding L, He C, Petralia R, Wenthold JR, Gallagher M, 
Huganir R (2003) Phosphorylation of the AMPA receptor GluR1 subunit is required for synaptic plasticity and retention of spatial memory. Cell. https://doi.org/10.1016/S0092-8674(03)00122-3

15. Tzingounis AV, Nicoll RA (2006) Arc/Arg3.1: linking gene expression to synaptic plasticity and memory. Neuron 52(3):403407. https://doi.org/10.1016/j.neuron.2006.10.016

16. Huang H-T, Liao C-K, Chiu W-T, Tzeng S-F (2017) Ligands of peroxisome proliferator-activated receptor-alpha promote glutamate transporter-1 endocytosis in astrocytes. Int J Biochem Cell Biol 86:42-53. https://doi.org/10.1016/j.biocel.2017.03.008

17. Zakrocka I, Targowska-Duda KM, Wnorowski A, Kocki T, Jóźwiak K, Turski WA (2017) Angiotensin II type 1 receptor blockers inhibit KAT II activity in the brain-its possible clinical applications. Neurotox Res 32(4):639-648. https://doi. org/10.1007/s12640-017-9781-2

18. Zakrocka I, Targowska-Duda KM, Wnorowski A, Kocki T, Jozwiak K, Turski WA (2018) Gemfibrozil decreases kynurenic acid production in rat brain in vitro. Folia Neuropathol 56(3):273-274. https://doi.org/10.5114/fn.2018.7870519

19. Melis M, Scheggi S, Carta G, Madeddu C, Lecca S, Luchicchi A, Cadeddu F, Frau R, Fattore L, Fadda P, Ennas MG, Castelli MP, Fratta W, Schilstrom B, Banni S, De Montis MG, Pistis M (2013) PPAR $\alpha$ regulates cholinergic-driven activity of midbrain dopamine neurons via a novel mechanism involving $\alpha 7$ nicotinic acetylcholine receptors. J Neurosci 33(14):6203-6211. https:// doi.org/10.1523/jneurosci.4647-12.2013

20. Melis M, Carta S, Fattore L, Tolu S, Yasar S, Goldberg SR, Fratta W, Maskos U, Pistis M (2010) Peroxisome proliferatoractivated receptors-alpha modulate dopamine cell activity through nicotinic receptors. Biol Psychiatry 68(3):256-264. https://doi.org/10.1016/j.biopsych.2010.04.016

21. Roy A, Pahan K (2015) PPAR $\alpha$ signaling in the hippocampus: crosstalk between fat and memory. J Neuroimmune Pharmacol 10(1):30-34. https://doi.org/10.1007/s11481-014-9582-9

22. Anderson CM, Swanson RA (2000) Astrocyte glutamate transport: review of properties, regulation, and physiological functions. Glia 32(1):1-14. https://doi.org/10.1002/10981136(200010)32:1\%3c1:aid-glia10\%3e3.0.co;2-w

23. Robinson MB (1998) Review Article The family of sodiumdependent glutamate transporters: a focus on the GLT-1/ EAAT2 subtype. Neurochem Int 33(6):479-491. https://doi. org/10.1016/S0197-0186(98)00055-2

24. Scott HA, Gebhardt FM, Mitrovic AD, Vandenberg RJ, Dodd PR (2011) Glutamate transporter variants reduce glutamate uptake in Alzheimer's disease. Neurobiol Aging 32(3):553. e551-553.e511. https://doi.org/10.1016/j.neurobiola ging.2010.03.008

25. Lauderback CM, Hackett JM, Huang FF, Keller JN, Szweda LI, Markesbery WR, Butterfield DA (2001) The glial glutamate transporter, GLT-1, is oxidatively modified by 4-hydroxy2-nonenal in the Alzheimer's disease brain: the role of A 1 1-42. J Neurochem 78(2):413-416. https://doi.org/10.104 6/j.1471-4159.2001.00451.x

26. Li S, Mallory M, Alford M, Tanaka S, Masliah E (1997) Glutamate transporter alterations in Alzheimer disease are possibly associated with abnormal APP expression. J Neuropathol Exp Neurol 56(8):901-911. https://doi.org/10.1097/00005072199708000-00008

27. Badawy AAB (2017) Kynurenine pathway of tryptophan metabolism: regulatory and functional aspects. Int J Tryptophan Res. https://doi.org/10.1177/1178646917691938

28. Wennström M, Nielsen HM, Orhan F, Londos E, Minthon L, Erhardt S (2014) Kynurenic acid levels in cerebrospinal fluid from patients with Alzheimer's disease or dementia with lewy bodies. Int J Tryptophan Res 7:1-7. https://doi.org/10.4137/IJTR. S13958
29. Gulaj E, Pawlak K, Bien B, Pawlak D (2010) Kynurenine and its metabolites in Alzheimer's disease patients. Adv Med Sci 55(2):204-211. https://doi.org/10.2478/v10039-010-0023-6

30. Deora GS, Kantham S, Chan S, Dighe SN, Veliyath SK, McColl G, Parat M-O, McGeary RP, Ross BP (2017) Multifunctional analogs of kynurenic acid for the treatment of Alzheimer's disease: synthesis, pharmacology, and molecular modeling studies. ACS Chem Neurosci 8(12):2667-2675. https://doi.org/10.1021/ acschemneuro.7b00229

31. Wang R, Reddy PH (2017) Role of glutamate and NMDA receptors in Alzheimer's disease. J Alzheimers Dis 57(4):1041-1048. https://doi.org/10.3233/JAD-160763

32. Raefsky SM, Mattson MP (2017) Adaptive responses of neuronal mitochondria to bioenergetic challenges: roles in neuroplasticity and disease resistance. Free Radic Biol Med 102:203-216. https ://doi.org/10.1016/j.freeradbiomed.2016.11.045

33. Peng X, Kim J, Zhou Z, Fink DJ, Mata M (2011) Neuronal NogoA regulates glutamate receptor subunit expression in hippocampal neurons. J Neurochem 119(6):1183-1193. https://doi.org/10 $.1111 / \mathrm{j} .1471-4159.2011 .07520 . \mathrm{x}$

34. Pierrot N, Ris L, Stancu I-C, Doshina A, Ribeiro F, Tyteca D, Baugé E, Lalloyer F, Malong L, Schakman O, Leroy K, KienlenCampard P, Gailly P, Brion J-P, Dewachter I, Staels B, Octave J-N (2019) Sex-regulated gene dosage effect of PPAR $\alpha$ on synaptic plasticity. Life Sci Alliance 2(2):e201800262. https://doi. org/10.26508/lsa.201800262

35. Schmitt WB, Sprengel R, Mack V, Draft RW, Seeburg PH, Deacon RMJ, Rawlins JNP, Bannerman DM (2005) Restoration of spatial working memory by genetic rescue of GluR-A-deficient mice. Nat Neurosci 8:270. https://doi.org/10.1038/nn1412

36. Mariani M, Malm T, Lamb R, Jay T, Neilson L, Casali B, Medarametla L, Landreth G (2017) Neuronally-directed effects of RXR activation in a mouse model of Alzheimer's disease. Sci Rep. https://doi.org/10.1038/srep42270

37. Moutinho M, Landreth GE (2017) Therapeutic potential of nuclear receptor agonists in Alzheimer's disease. J Lipid Res 58(10):1937-1949. https://doi.org/10.1194/jlr.R075556

38. Zolezzi JM, Santos MJ, Bastías-Candia S, Pinto C, Godoy JA, Inestrosa NC (2017) PPARs in the central nervous system: roles in neurodegeneration and neuroinflammation. Biol Rev 92(4):2046-2069. https://doi.org/10.1111/brv.12320

39. Nam KN, Mounier A, Fitz NF, Wolfe C, Schug J, Lefterov I, Koldamova R (2016) RXR controlled regulatory networks identified in mouse brain counteract deleterious effects of $A \beta$ oligomers. Sci Rep 6:24048-24048. https://doi.org/10.1038/srep24048

40. Mounier A, Georgiev D, Nam KN, Fitz NF, Castranio EL, Wolfe CM, Cronican AA, Schug J, Lefterov I, Koldamova R (2015) Bexarotene-activated retinoid $\mathrm{x}$ receptors regulate neuronal differentiation and dendritic complexity. J Neurosci 35(34):1186211876. https://doi.org/10.1523/JNEUROSCI.1001-15.2015

41. de la Monte SM, Wands JR (2006) Molecular indices of oxidative stress and mitochondrial dysfunction occur early and often progress with severity of Alzheimer's disease. J Alzheimer's Dis. https://doi.org/10.3233/JAD-2006-9209

42. Brune S, Kölsch H, Ptok U, Majores M, Schulz A, Schlosser R, Rao ML, Maier W, Heun R (2003) Polymorphism in the peroxisome proliferator-activated receptor $\alpha$ gene influences the risk for Alzheimer's disease. J Neural Transm 110(9):1041-1050. https ://doi.org/10.1007/s00702-003-0018-6

43. Lecarpentier Y, Claes V, Duthoit G, Hébert J-L (2014) Circadian rhythms, Wnt/beta-catenin pathway and PPAR alpha/gamma profiles in diseases with primary or secondary cardiac dysfunction. Front Physiol 5:429-429. https://doi.org/10.3389/fphys 2014.00429

44. Finck BN, Kelly DP (2002) Peroxisome proliferator-activated receptor $\alpha(\operatorname{PPAR} \alpha)$ signaling in the gene regulatory 
control of energy metabolism in the normal and diseased heart. J Mol Cell Cardiol 34(10):1249-1257. https://doi.org/10.1006/ jmcc. 2002.2061

45. Feige JN, Gelman L, Michalik L, Desvergne B, Wahli W (2006) From molecular action to physiological outputs: peroxisome proliferator-activated receptors are nuclear receptors at the crossroads of key cellular functions. Prog Lipid Res 45(2):120-159. https://doi.org/10.1016/j.plipres.2005.12.002

46. Djouadi F, Lecarpentier Y, Hébert J-L, Charron P, Bastin J, Coirault C (2009) A potential link between peroxisome proliferator-activated receptor signalling and the pathogenesis of arrhythmogenic right ventricular cardiomyopathy. Cardiovasc Res 84(1):83-90. https://doi.org/10.1093/cvr/cvp183

47. Roy A, Jana M, Kundu M, Corbett GT, Rangaswamy SB, Mishra RK, Luan C-H, Gonzalez FJ, Pahan K (2015) HMG-CoA reductase inhibitors bind to PPAR $\alpha$ to upregulate neurotrophin expression in the brain and improve memory in mice. Cell Metab 22(2):253-265. https://doi.org/10.1016/j.cmet.2015.05.022

48. Corbett GT, Gonzalez FJ, Pahan K (2015) Activation of peroxisome proliferator-activated receptor $\alpha$ stimulates ADAM10mediated proteolysis of APP. Proc Natl Acad Sci USA 112(27):8445-8450. https://doi.org/10.1073/pnas.1504890112

49. Vallée A, Lecarpentier Y (2016) Alzheimer disease: crosstalk between the canonical Wnt/beta-catenin pathway and PPARs alpha and gamma. Front Neurosci 10:459-459. https://doi. org/10.3389/fnins.2016.00459

50. Zhang H, Gao Y, Qiao P-f, Zhao F-1, Yan Y (2015) PPAR- $\alpha$ agonist regulates amyloid- $\beta$ generation via inhibiting BACE-1 activity in human neuroblastoma SH-SY5Y cells transfected with APPswe gene. Mol Cell Biochem 408(1):37-46. https:// doi.org/10.1007/s11010-015-2480-5

51. Zhang H, Gao Y, Qiao P-f, Zhao F-1, Yan Y (2014) Fenofibrate reduces amyloidogenic processing of APP in APP/PS1 transgenic mice via PPAR- $\alpha / P I 3-K$ pathway. Int J Dev Neurosci 38:223231. https://doi.org/10.1016/j.ijdevneu.2014.10.004

52. Kummer MP, Schwarzenberger R, Sayah-Jeanne S, Dubernet M, Walczak R, Hum DW, Schwartz S, Axt D, Heneka MT (2015) Pan-PPAR modulation effectively protects APP/PS1 mice from amyloid deposition and cognitive deficits. Mol Neurobiol 51(2):661-671. https://doi.org/10.1007/s12035-014-8743-4

53. Blasko I, Jungwirth S, Jellinger K, Kemmler G, Krampla W, Weissgram S, Wichart I, Tragl KH, Hinterhuber H, Fischer P (2008) Effects of medications on plasma amyloid beta (A $\beta$ ) 42: longitudinal data from the VITA cohort. J Psychiatr Res 42(11):946-955. https://doi.org/10.1016/j.jpsychires .2007 .10 .010

54. Chandra S, Roy A, Jana M, Pahan K (2019) Cinnamic acid activates PPAR $\alpha$ to stimulate lysosomal biogenesis and lower amyloid plaque pathology in an Alzheimer's disease mouse model. Neurobiol Dis 124:379-395. https://doi.org/10.1016/j. nbd.2018.12.007

55. Chandra S, Pahan K (2018) Gemfibrozil, a lipid-lowering drug, attenuates amyloid plaque pathology and enhances memory via PPAR $\alpha$. Alzheimer's Dement 14(7):P1655-P1656. https://doi. org/10.1016/j.jalz.2018.06.3020

56. Domingues C, da Cruz E, Silva OAB, Henriques AG (2017) Impact of cytokines and chemokines on Alzheimer's disease neuropathological hallmarks. Curr Alzheimer Res 14(8):870-882. https://doi.org/10.2174/1567205014666170317113606

57. Wang R, Li JJ, Diao S, Kwak Y-D, Liu L, Zhi L, Büeler H, Bhat NR, Williams RW, Park EA, Liao F-F (2013) Metabolic stress modulates Alzheimer's $\beta$-secretase gene transcription via SIRT1PPAR $\gamma$-PGC-1 in neurons. Cell Metab 17(5):685-694. https:// doi.org/10.1016/j.cmet.2013.03.016
58. Selkoe DJ (2001) Alzheimer's disease: genes, proteins, and therapy. Physiol Rev 81(2):741-766. https://doi.org/10.1152/physr ev.2001.81.2.741

59. Selkoe DJ, Hardy J (2016) The amyloid hypothesis of Alzheimer's disease at 25 years. EMBO Mol Med 8(6):595-608. https ://doi.org/10.15252/emmm.201606210

60. Qiang L, Wang L, Kon N, Zhao W, Lee S, Zhang Y, Rosenbaum M, Zhao Y, Gu W, Farmer SR, Accili D (2012) Brown remodeling of white adipose tissue by SirT1-dependent deacetylation of Ppary. Cell 150(3):620-632. https://doi.org/10.1016/j. cell.2012.06.027

61. Sweeney G, Song J (2016) The association between PGC-1 $\alpha$ and Alzheimer's disease. Anat Cell Biol 49(1):1-6. https://doi. org/10.5115/acb.2016.49.1.1

62. Katsouri L, Lim YM, Blondrath K, Eleftheriadou I, Lombardero L, Birch AM, Mirzaei N, Irvine EE, Mazarakis ND, Sastre M (2016) PPAR $\gamma$-coactivator- $1 \alpha$ gene transfer reduces neuronal loss and amyloid- $\beta$ generation by reducing $\beta$-secretase in an Alzheimer's disease model. Proc Natl Acad Sci USA 113(43):1229212297. https://doi.org/10.1073/pnas.1606171113

63. Qin W, Haroutunian V, Katsel P, Cardozo CP, Ho L, Buxbaum JD, Pasinetti GM (2009) PGC-1alpha expression decreases in the Alzheimer disease brain as a function of dementia. Arch Neurol 66(3):352-361. https://doi.org/10.1001/archneurol.2008.588

64. Wenz T (2011) Mitochondria and PGC-1 $\alpha$ in aging and ageassociated diseases. J Aging Res 2011:810619-810619. https:// doi.org/10.4061/2011/810619

65. Cheng A, Wan R, Yang J-L, Kamimura N, Son TG, Ouyang X, Luo Y, Okun E, Mattson MP (2012) Involvement of PGC-1 $\alpha$ in the formation and maintenance of neuronal dendritic spines. Nat Commun 3:1250-1250. https://doi.org/10.1038/ncomms2238

66. Lamichane S, Dahal Lamichane B, Kwon S-M (2018) Pivotal roles of peroxisome proliferator-activated receptors (PPARs) and their signal cascade for cellular and whole-body energy homeostasis. Int J Mol Sci 19(4):949. https://doi.org/10.3390/ijms1 9040949

67. Tachibana K, Takeuchi K, Inada H, Yamasaki D, Ishimoto K, Tanaka T, Hamakubo T, Sakai J, Kodama T, Doi T (2009) Regulation of the human SLC25A20 expression by peroxisome proliferator-activated receptor alpha in human hepatoblastoma cells. Biochem Biophys Res Commun 389(3):501-505. https:// doi.org/10.1016/j.bbrc.2009.09.018

68. Lee GY, Kim NH, Zhao Z-S, Cha BS, Kim YS (2004) Peroxisomal-proliferator-activated receptor alpha activates transcription of the rat hepatic malonyl-CoA decarboxylase gene: a key regulation of malonyl-CoA level. Biochem J 378(Pt 3):983-990. https ://doi.org/10.1042/BJ20031565

69. Kuhl JE, Ruderman NB, Musi N, Goodyear LJ, Patti ME, Crunkhorn S, Dronamraju D, Thorell A, Nygren J, Ljungkvist O, Degerblad M, Stahle A, Brismar TB, Andersen KL, Saha AK, Efendic S, Bavenholm PN (2006) Exercise training decreases the concentration of malonyl-CoA and increases the expression and activity of malonyl-CoA decarboxylase in human muscle. Am J Physiol Endocrinol Metab 290(6):E1296-E1303. https://doi. org/10.1152/ajpendo.00341.2005

70. Abbot EL, McCormack JG, Reynet C, Hassall DG, Buchan KW, Yeaman SJ (2005) Diverging regulation of pyruvate dehydrogenase kinase isoform gene expression in cultured human muscle cells. FEBS J 272(12):3004-3014. https://doi.org/10.11 11/j.1742-4658.2005.04713.x

71. Bell DR, Elcombe CR (1991) Induction of acyl-CoA oxidase and cytochrome P450IVA1 RNA in rat primary hepatocyte culture by peroxisome proliferators. Biochem J 280(Pt 1):249-253. https:// doi.org/10.1042/bj2800249 
72. Dominy JE, Puigserver P (2013) Mitochondrial biogenesis through activation of nuclear signaling proteins. Cold Spring Harb Perspect Biol 5(7):a015008. https://doi.org/10.1101/cshpe rspect.a015008

73. Jornayvaz FR, Shulman GI (2010) Regulation of mitochondrial biogenesis. Essays Biochem 47:69-84. https://doi.org/10.1042/ bse 0470069

74. Jęśko H, Strosznajder RP (2016) Sirtuins and their interactions with transcription factors and poly(ADP-ribose) polymerases. Folia Neuropathol 54(3):212-233. https://doi.org/10.5114/ fn.2016.62531

75. Jęśko H, Wencel P, Strosznajder RP, Strosznajder JB (2017) Sirtuins and their roles in brain aging and neurodegenerative disorders. Neurochem Res 42(3):876-890. https://doi.org/10.1007/ s11064-016-2110-y

76. Strosznajder RP, Czubowicz K, Jesko H, Strosznajder JB (2010) Poly(ADP-ribose) metabolism in brain and its role in ischemia pathology. Mol Neurobiol 41(2):187-196. https://doi. org/10.1007/s12035-010-8124-6

77. Strosznajder J, Czapski G, Adamczyk A, Strosznajder R (2012) Poly(ADP-ribose) polymerase-1 in amyloid beta toxicity and Alzheimer's disease. Mol Neurobiol 46(1):78-84. https://doi. org/10.1007/s12035-012-8258-9

78. Bai P, Cantó C, Oudart H, Brunyánszki A, Cen Y, Thomas C, Yamamoto H, Huber A, Kiss B, Houtkooper RH, Schoonjans K, Schreiber V, Sauve AA, Menissier-de Murcia J, Auwerx J (2011) PARP-1 inhibition increases mitochondrial metabolism through SIRT1 activation. Cell Metab 13(4):461-468. https:// doi.org/10.1016/j.cmet.2011.03.004

79. Lapucci A, Pittelli M, Rapizzi E, Felici R, Moroni F, Chiarugi A (2011) Poly(ADP-ribose) polymerase-1 is a nuclear epigenetic regulator of mitochondrial DNA repair and transcription. Mol Pharmacol 79(6):932-940. https://doi.org/10.1124/ mol.110.070110

80. Berger NA, Besson VC, Boulares AH, Bürkle A, Chiarugi A, Clark RS, Curtin NJ, Cuzzocrea S, Dawson TM, Dawson VL, Haskó G, Liaudet L, Moroni F, Pacher P, Radermacher P, Salzman AL, Snyder SH, Soriano FG, Strosznajder RP, Sümegi B, Swanson RA, Szabo C (2018) Opportunities for the repurposing of PARP inhibitors for the therapy of non-oncological diseases. Br J Pharmacol 175(2):192-222. https://doi.org/10.1111/ bph. 13748

81. Rossi MN, Carbone M, Mostocotto C, Mancone C, Tripodi M, Maione R, Amati P (2009) Mitochondrial localization of PARP-1 requires interaction with mitofilin and is involved in the maintenance of mitochondrial DNA integrity. J Biol Chem 284(46):31616-31624. https://doi.org/10.1074/jbc.M109.02588 2

82. Chinnery PF, Hudson G (2013) Mitochondrial genetics. Br Med Bull 106(1):135-159. https://doi.org/10.1093/bmb/ldt017

83. D'Souza AR, Minczuk M (2018) Mitochondrial transcription and translation: overview. Essays Biochem 62(3):309-320. https ://doi.org/10.1042/EBC20170102

84. Esmaeili MA, Yadav S, Gupta RK, Waggoner GR, Deloach A, Calingasan NY, Beal MF, Kiaei M (2016) Preferential PPAR- $\alpha$ activation reduces neuroinflammation, and blocks neurodegeneration in vivo. Hum Mol Genet 25(2):317-327. https://doi. org $/ 10.1093 / \mathrm{hmg} / \mathrm{ddv} 477$

85. Fidaleo M, Fanelli F, Paola Cerù M, Moreno S (2014) Neuroprotective properties of peroxisome proliferator-activated receptor alpha (PPAR) and its lipid ligands. Curr Med Chem 21(24):2803-2821

86. Moreno S, Cerù MP (2015) In search for novel strategies towards neuroprotection and neuroregeneration: is PPAR $\alpha$ a promising therapeutic target? Neural Regen Res 10(9):1409-1412. https:// doi.org/10.4103/1673-5374.165313
87. Hall MG, Quignodon L, Desvergne B (2008) Peroxisome proliferator-activated receptor beta/delta in the brain: facts and hypothesis. PPAR Res 2008:780452-780452. https://doi. org/10.1155/2008/780452

88. Fan W, Evans R (2015) PPARs and ERRs: molecular mediators of mitochondrial metabolism. Curr Opin Cell Biol 33:49-54. https://doi.org/10.1016/j.ceb.2014.11.002

89. Cui L, Jeong H, Borovecki F, Parkhurst CN, Tanese N, Krainc D (2006) Transcriptional repression of PGC- $1 \alpha$ by mutant huntingtin leads to mitochondrial dysfunction and neurodegeneration. Cell 127(1):59-69. https://doi.org/10.1016/j.cell.2006.09.015

90. Weydt P, Pineda VV, Torrence AE, Libby RT, Satterfield TF, Lazarowski Eduardo R, Gilbert ML, Morton GJ, Bammler TK, Strand AD, Cui L, Beyer RP, Easley CN, Smith AC, Krainc D, Luquet S, Sweet Ian R, Schwartz MW, La Spada AR (2006) Thermoregulatory and metabolic defects in Huntington's disease transgenic mice implicate PGC- $1 \alpha$ in Huntington's disease neurodegeneration. Cell Metab 4(5):349-362. https://doi. org/10.1016/j.cmet.2006.10.004

91. Thau N, Knippenberg S, Körner S, Rath KJ, Dengler R, Petri S (2012) Decreased mRNA expression of PGC- $1 \alpha$ and PGC- $1 \alpha-$ regulated factors in the SOD1G93A ALS mouse model and in human sporadic ALS. J Neuropathol Exp Neurol 71(12):10641074. https://doi.org/10.1097/NEN.0b013e318275df4b

92. Lv J, Jiang S, Yang Z, Hu W, Wang Z, Li T, Yang Y (2018) PGC- $1 \alpha$ sparks the fire of neuroprotection against neurodegenerative disorders. Ageing Res Rev 44:8-21. https://doi. org/10.1016/j.arr.2018.03.004

93. St-Pierre J, Drori S, Uldry M, Silvaggi JM, Rhee J, Jäger S, Handschin C, Zheng K, Lin J, Yang W, Simon DK, Bachoo R, Spiegelman BM (2006) Suppression of reactive oxygen species and neurodegeneration by the PGC-1 transcriptional coactivators. Cell 127(2):397-408. https://doi.org/10.1016/j.cell.2006.09.024

94. Uppalapati D, Das NR, Gangwal RP, Damre MV, Sangamwar AT, Sharma SS (2014) Neuroprotective potential of peroxisome proliferator activated receptor- $\alpha$ agonist in cognitive impairment in Parkinson's disease: behavioral, biochemical, and PBPK profile. PPAR Res 2014:753587-753587. https://doi. org/10.1155/2014/753587

95. Bose A, Beal MF (2016) Mitochondrial dysfunction in Parkinson's disease. J Neurochem 139(S1):216-231. https://doi. org/10.1111/jnc. 13731

96. Di Giacomo E, Benedetti E, Cristiano L, Antonosante A, d'Angelo M, Fidoamore A, Barone D, Moreno S, Ippoliti R, Cerù MP, Giordano A, Cimini A (2016) Roles of PPAR transcription factors in the energetic metabolic switch occurring during adult neurogenesis. Cell Cycle 16(1):59-72. https://doi. org/10.1080/15384101.2016.1252881

97. Pinto M, Nissanka N, Peralta S, Brambilla R, Diaz F, Moraes CT (2016) Pioglitazone ameliorates the phenotype of a novel Parkinson's disease mouse model by reducing neuroinflammation. Mol Neurodegener 11:25-25. https://doi.org/10.1186/s1302 4-016-0090-7

98. Mäkelä J, Tselykh TV, Kukkonen JP, Eriksson O, Korhonen LT, Lindholm D (2016) Peroxisome proliferator-activated receptor- $\gamma$ $(\mathrm{PPAR} \gamma)$ agonist is neuroprotective and stimulates PGC- $1 \alpha$ expression and CREB phosphorylation in human dopaminergic neurons. Neuropharmacology 102:266-275. https://doi. org/10.1016/j.neuropharm.2015.11.020

99. Carta AR, Frau L, Pisanu A, Wardas J, Spiga S, Carboni E (2011) Rosiglitazone decreases peroxisome proliferator receptor-gamma levels in microglia and inhibits TNF-alpha production: new evidences on neuroprotection in a progressive Parkinson's disease model. Neuroscience 194:250-261. https://doi.org/10.1016/j. neuroscience.2011.07.046 
100. Nisbett KE, Pinna G (2018) Emerging therapeutic role of PPAR- $\alpha$ in cognition and emotions. Front Pharmacol 2(9):998. https://doi.org/10.3389/fphar.2018.00998

101. Hillard CJ (2018) Circulating endocannabinoids: from whence do they come and where are they going? Neuropsychopharmacology 43(1):155-172. https://doi.org/10.1038/npp.2017.130

102. Locci A, Pinna G (2017) Neurosteroid biosynthesis downregulation and changes in $\mathrm{GABA}(\mathrm{A})$ receptor subunit composition: a biomarker axis in stress-induced cognitive and emotional impairment. Br J Pharmacol 174(19):3226-3241. https://doi. org/10.1111/bph.13843

103. Jiang B, Wang Y-J, Wang H, Song L, Huang C, Zhu Q, Wu F, Zhang W (2017) Antidepressant-like effects of fenofibrate in mice via the hippocampal brain-derived neurotrophic factor signalling pathway. Br J Pharmacol 174(2):177-194. https://doi. org/10.1111/bph.13668

104. Krishnan V, Nestler EJ (2008) The molecular neurobiology of depression. Nature 455(7215):894-902. https://doi.org/10.1038/ nature 07455

105. Lee B-H, Kim Y-K (2010) The roles of BDNF in the pathophysiology of major depression and in antidepressant treatment. Psychiatry Investig 7(4):231-235. https://doi.org/10.4306/ pi.2010.7.4.231

106. Kemp DE, Schinagle M, Gao K, Conroy C, Ganocy SJ, IsmailBeigi F, Calabrese JR (2014) PPAR- $\gamma$ agonism as a modulator of mood: proof-of-concept for pioglitazone in bipolar depression. CNS Drugs 28(6):571-581. https://doi.org/10.1007/s4026 3-014-0158-2

107. Zeinoddini A, Sorayani M, Hassanzadeh E, Arbabi M, Farokhnia M, Salimi S, Ghaleiha A, Akhondzadeh S (2015) Pioglitazone adjunctive therapy for depressive episode of bipolar disorder: a randomized, double-blind, placebo-controlled trial. Depress Anxiety 32(3):167-173. https://doi.org/10.1002/da.22340

108. Kemp DE, Ismail-Beigi F, Calabrese JR (2009) Antidepressant response associated with pioglitazone: support for an overlapping pathophysiology between major depression and metabolic syndrome. Am J Psychiatry 166(5):619-619. https://doi. org/10.1176/appi.ajp.2008.08081195

109. Kemp DE, Ismail-Beigi F, Ganocy SJ, Conroy C, Gao K, Obral S, Fein E, Findling RL, Calabrese JR (2012) Use of insulin sensitizers for the treatment of major depressive disorder: a pilot study of pioglitazone for major depression accompanied by abdominal obesity. J Affect Disord 136(3):1164-1173. https:// doi.org/10.1016/j.jad.2011.06.033

110. Lin KW, Wroolie TE, Robakis T, Rasgon NL (2015) Adjuvant pioglitazone for unremitted depression: clinical correlates of treatment response. Psychiatry Res 230(3):846-852. https://doi. org/10.1016/j.psychres.2015.10.013

111. Puddifoot C, Martel M-A, Soriano FX, Camacho A, Vidal-Puig A, Wyllie DJA, Hardingham GE (2012) PGC-1 $\alpha$ negatively regulates extrasynaptic NMDAR activity and excitotoxicity. J Neurosci 32(20):6995-7000. https://doi.org/10.1523/JNEUR OSCI.6407-11.2012

112. Sepanjnia K, Modabbernia A, Ashrafi M, Modabbernia M-J, Akhondzadeh S (2012) Pioglitazone adjunctive therapy for moderate-to-severe major depressive disorder: randomized double-blind placebo-controlled trial. Neuropsychopharmacology 37(9):2093-2100. https://doi.org/10.1038/npp.2012.58

113. Cohen D (2010) Rosiglitazone: what went wrong? BMJ 341:c4848. https://doi.org/10.1136/bmj.c4848

114. Barone R, Rizzo R, Tabbì G, Malaguarnera M, Frye RE, Bastin J (2019) Nuclear peroxisome proliferator-activated receptors (PPARs) as therapeutic targets of resveratrol for autism spectrum disorder. Int J Mol Sci 20(8):1878. https://doi.org/10.3390/ijms2 0081878
115. D’Agostino G, Cristiano C, Lyons DJ, Citraro R, Russo E, Avagliano C, Russo R, Raso GM, Meli R, De Sarro G, Heisler LK, Calignano A (2015) Peroxisome proliferator-activated receptor alpha plays a crucial role in behavioral repetition and cognitive flexibility in mice. Mol Metab 4(7):528-536. https://doi. org/10.1016/j.molmet.2015.04.005

116. Grover S, Kumar P, Singh K, Vikram V, Budhiraja RD (2013) Possible beneficial effect of peroxisome proliferator-activated receptor (PPAR) $-\alpha$ and $\gamma$ agonist against a rat model of oral dyskinesia. Pharmacol Biochem Behav 111:17-23. https://doi. org/10.1016/j.pbb.2013.08.001

117. Grings M, Moura AP, Parmeggiani B, Pletsch JT, Cardoso GMF, August PM, Matté C, Wyse ATS, Wajner M, Leipnitz G (2017) Bezafibrate prevents mitochondrial dysfunction, antioxidant system disturbance, glial reactivity and neuronal damage induced by sulfite administration in striatum of rats: implications for a possible therapeutic strategy for sulfite oxidase deficiency. Biochimica et Biophysica Acta (BBA) 1863(9):2135-2148. https:// doi.org/10.1016/j.bbadis.2017.05.019

118. Ferguson LB, Most D, Blednov YA, Harris RA (2014) PPAR agonists regulate brain gene expression: relationship to their effects on ethanol consumption. Neuropharmacology 86:397407. https://doi.org/10.1016/j.neuropharm.2014.06.024

119. Inoue H, Jiang X-F, Katayama T, Osada S, Umesono K, Namura S (2003) Brain protection by resveratrol and fenofibrate against stroke requires peroxisome proliferator-activated receptor $\alpha$ in mice. Neurosci Lett 352(3):203-206. https://doi.org/10.1016/j. neulet.2003.09.001

120. Raso GM, Esposito E, Vitiello S, Iacono A, Santoro A, D’Agostino G, Sasso O, Russo R, Piazza PV, Calignano A, Meli R (2011) Palmitoylethanolamide stimulation induces allopregnanolone synthesis in C6 cells and primary astrocytes: involvement of peroxisome-proliferator activated receptor- $\alpha$. J Neuroendocrinol 23(7):591-600. https://doi.org/10.111 1/j.1365-2826.2011.02152.x

121. Moran EP, Ma J-X (2015) Therapeutic effects of PPAR $\alpha$ on neuronal death and microvascular impairment. PPAR Res 2015:595426-595426. https://doi.org/10.1155/2015/595426

122. Amadei C, Kow R, Nawaz Z (2018) Amyloid precursor protein in autism spectrum disorder. J Mol Genet Med 12(2):342

123. Guglielmotto M, Monteleone D, Boido M, Piras A, Giliberto L, Borghi R, Vercelli A, Fornaro M, Tabaton M, Tamagno E (2012) A 1 1-42-mediated down-regulation of Uch-L1 is dependent on NF- $\mathrm{\kappa B}$ activation and impaired BACE1 lysosomal degradation. Aging Cell 11(5):834-844. https://doi.org/10.111 1/j.1474-9726.2012.00854.x

124. Roßner S, Sastre M, Bourne K, Lichtenthaler SF (2006) Transcriptional and translational regulation of BACE1 expressionimplications for Alzheimer's disease. Prog Neurobiol 79(2):95111. https://doi.org/10.1016/j.pneurobio.2006.06.001

125. Adeghate E, Adem A, Hasan MY, Tekes K, Kalasz H (2011) Medicinal chemistry and actions of dual and pan PPAR modulators. Open Med Chem J 5(Suppl 2):93-98. https://doi. org/10.2174/1874104501105010093

126. Wenz T (2009) PGC-1 $\alpha$ activation as a therapeutic approach in mitochondrial disease. IUBMB Life 61(11):1051-1062. https:// doi.org/10.1002/iub.261

127. Adedapo A, Asunloye O, Adeoye B (2018) Peroxisome proliferator-activated receptor-review. Int J Biochem Res Rev 21(2):1-19. https://doi.org/10.9734/ijbcrr/2018/40221

128. Singh M, Pathak D, Sharma GK, Sharma CS (2011) Peroxisome proliferator-activated receptors (PPARS): a target with a broad therapeutic potential for human diseases: an overview. Pharmacologyonline 2:58-89 
129. Rigano D, Sirignano C, Taglialatela-Scafati O (2017) The potential of natural products for targeting PPAR $\alpha$. Acta Pharm Sin B 7(4):427-438

130. Contreras AV, Torres N, Tovar AR (2013) PPAR- $\alpha$ as a key nutritional and environmental sensor for metabolic adaptation. Adv Nutr 4(4):439-452. https://doi.org/10.3945/an.113.003798

131. Puligheddu M, Melis M, Pillolla G, Milioli G, Parrino L, Terzano GM, Aroni S, Sagheddu C, Marrosu F, Pistis M, Muntoni AL (2017) Rationale for an adjunctive therapy with fenofibrate in pharmacoresistant nocturnal frontal lobe epilepsy. Epilepsia 58(10):1762-1770. https://doi.org/10.1111/epi.13863

132. Luo R, Su L-Y, Li G, Yang J, Liu Q, Yang L-X, Zhang D-F, Zhou H, Xu M, Fan Y, Li J, Yao Y-G (2020) Activation of PPARAmediated autophagy reduces Alzheimer disease-like pathology and cognitive decline in a murine model. Autophagy 16(1):5269. https://doi.org/10.1080/15548627.2019.1596488

133. Inestrosa NC, Carvajal FJ, Zolezzi JM, Tapia-Rojas C, Serrano F, Karmelic D, Toledo EM, Toro A, Toro J, Santos MJ (2013) Peroxisome proliferators reduce spatial memory impairment, synaptic failure, and neurodegeneration in brains of a double transgenic mice model of Alzheimer's disease. J Alzheimers Dis 33(4):941-959. https://doi.org/10.3233/JAD-2012-120397

134. Barbiero JK, Santiago R, Tonin FS, Boschen S, da Silva LM, de Paula Werner MF, da Cunha C, Lima MMS, Vital MABF
(2014) PPAR- $\alpha$ agonist fenofibrate protects against the damaging effects of MPTP in a rat model of Parkinson's disease. Prog Neuro-Psychopharmacol Biol Psychiatry 53:35-44. https://doi. org/10.1016/j.pnpbp.2014.02.009

135. Deplanque D, Gelé P, Pétrault O, Six I, Furman C, Bouly M, Nion S, Dupuis B, Leys D, Fruchart J-C, Cecchelli R, Staels B, Duriez P, Bordet R (2003) Peroxisome proliferator-activated receptor-alpha activation as a mechanism of preventive neuroprotection induced by chronic fenofibrate treatment. J Neurosci 23(15):6264-6271. https://doi.org/10.1523/JNEUROSCI.23-1506264.2003

136. D'Orio B, Fracassi A, Cerù MP, Moreno S (2017) Targeting PPARalpha in Alzheimer's disease. Curr Alzheimer Res 15(4):345-354. https://doi.org/10.2174/15672050146661705050 94549

Publisher's Note Springer Nature remains neutral with regard to jurisdictional claims in published maps and institutional affiliations. 